\title{
LANGUAGE CONTACT IN AMAZONIA
}

ALEXANDRA Y. AIKHENVALD

The Cairns Institute

James Cook University 


\section{OXFORD}

Great Clarendon Street. Oxford OX2 6DP

Oxford University Press is a department of the University of Oxford.

It furthers the University's objective of excellence in research, scholarship, and education by publishing worldwide in

Oxford New York

Auckland Bangkok Buenos Aires Cape Town Chennai Dares Salaam Delhi Hong Kong Istanbul Karachi Kolkata

Kuala Lumpur Madrid Melbourne Mexico City Mumbai Nairobi São Paulo Shanghai Taipei Tokyo Toronto

Oxford is a registered trade mark of Oxford University Press in the UK and in certain other countries

Published in the United States

by Oxford University Press Inc., New York

$$
\text { (C) A. Y. Aikhenvald }
$$

The moral rights of the author have been asserted

Database right Oxford University Press (maker)

First published 2002

First published in paperback 2010 (with corrections)

All rights reserved. No part of this publication may be reproduced, stored in a retrieval system, or transmitted, in any form or by any means, without the prior permission in writing of Oxford University Press,

or as expressly permitted by law, or under terms agreed with the appropriate reprographics rights organization. Enquiries concerning reproduction outside the scope of the above should be sent to the Rights Department, Oxford University Press, at the address above

You must not circulate this book in any other binding or cover and you must impose this same condition on any acquirer

A catalogue record for this title is availahle from the British Library

Library of Congress Cataloging in Publication Data (Data applied for)

ISBN 9/8-U-19-925785-0 (Hbk.)

ISBN 978-0-19-958824-4 (Pbk.)

13579108642

Typeset by SPI Publisher Services, Pondicherry, India

Digitally printed and bound in Great Britain by

CPI Antony Rowe, Chippenham and Eastbourne 
To the memory of my late grandfather, Moisei Rosman ('Misha Gorb'), 1894-1937 


\section{Contents}

Preface xiii

Acknowledgements $\quad \mathrm{xv}$

List of Abbreviations $\quad$ xix

List of Tables and Figures $\quad x x i$

List of Plates xxiv

Map. Arawak and Tucanoan Languages in north-western Amazonia $\quad$ xxv

1. Language Contact and Language Change in Amazonia 1

1.1. What this Book is About 1

1.2. Linguistic Diffusion and Grammatical Borrowing 3

1.2.1. Types of linguistic change 3

1.2.2. Linguistic areas 7

1.2.3. Sociolinguistic parameters in language contact 9

1.2.4. Which linguistic features are likely to be
borrowed?

1.3. Arawak-Tucanoan Contact in Amazonia 14

1.3.1. Arawak and Tucanoan languages: general

1.3.2. Known instances of Arawak-Tucanoan

1.4. Linguistic Situation in the Vaupés Area 17

1.4.1. Languages spoken in the Vaupés 17

1.4.2. The traditional Vaupés area 21

1.4.3. A new contact situation: Tucano in the Vaupés
area

1.5. Materials Used for this Study 28

1.6. The Structure of this Book 30

2. Diffusional Phenomena in Phonology 33

2.1. Indirect Diffusion of Phonemes 34

2.1.1. Phonological systems of East Tucanoan languages and of Tariana 34

2.1.2. Consonants of Tariana and the East Tucanoan influence 36

2.1.3. Vowels of Tariana and the East Tucanoan influence 
2.2. Indirect Diffusion and Syllable Structure

2.3. Indirect Diffusion and Processes within a Phonological Word:

Pitch Accent and Intonation Patterns

2.3.1. Palatalization of $y$ in a word- or root-initial position

2.3.2. Nasalization

2.3.3. Alternation between a flap and a voiced dental stop

2.3.4. Homorganic vowel insertion

2.3.5. Syllable reduction

2.3.6. Glottalization, pitch accent, and intonation patterns

2.4. Direct Diffusion and Phonology

2.5. Indirect and Direct Diffusion in Phonology

2.6. Contact-Induced Changes in the Phonologies of Retuarã and Yucuna

3. Typological Profile and Pronominal Systems of East Tucanoan and Arawak Languages

3.1. Typological Profile and the Structure of a Grammatical Word in East Tucanoan and in Tariana

3.2. Personal Pronouns in East Tucanoan and in Arawak

3.3. Cross-Referencing Affixes in East Tucanoan and in Tariana

3.4. Contact-Induced Changes in Tariana and in East Tucanoan Cross-referencing

3.5. Contact-Induced Changes in Retuarã and in Yucuna Cross-Referencing

3.6. Summary

4. Nominal Categories and Diffusion

4.1. Possession

4.1.1. Possession marking in Tucanoan and in

Arawak

4.1.2. Contact-induced changes in Tariana and in East Tucanoan possession marking

4.1.3. Contact-induced changes in younger pcoplc's Tariana under Tucano influence

4.1.4. Contact-induced changes in Retuarã and in Yucuna 


\section{Contents ix}

4.2.1. Classifiers, genders, and animacy in Arawak and in Tucanoan

4.2.2. Contact-induced changes in Tariana

4.2.3. Contact-induced changes in Retuarã and in Yucuna

4.3. Number

4.4. Nominal Past and Vocative Forms

4.5. Grammatical Relations and Case

4.5.1. Contact-induced changes in Tariana

4.5.2. Contact-induced changes in Retuarã 107

4.6. Restructuring of Numerals 107

4.7. Restructuring of Demonstratives 108

$\begin{array}{ll}\text { 4.8. Summary } & 110\end{array}$

5. The Diffusion of Verbal Categories 113

5.1. Valency-Changing Derivations 113

5.1.1. Passive 114

5.1.2. Causative 116

$\begin{array}{ll}\text { 5.2. Tense and Evidentiality } & 117\end{array}$

5.3. Commands 129

5.4. Negation 131

5.5. Verb-Compounding Strategies 136

5.6. Complex Predicates 144

5.7. Marking Predicate Categories 146

$\begin{array}{ll}\text { 5.8. Summary } & 148\end{array}$

6. Diffusional Phenomena in Syntax and in Discourse 153

6.1. Borrowed Clause Types 153

6.2. Clause Linking Techniques and Dependent Clauses 158

6.3. Word Order and Constituent Order 166

6.4. Discourse Organization 168

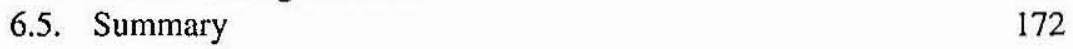

7. The Impact of Portuguese on Tariana 175

7.1. Lexical Loans from Portuguese 176

7.2. Loan Grammatical Morphemes 179

7.3. Indirect Diffusion from Portuguese 182

7.4. Does Tariana have a 'Loan Phonology'? 185

$\begin{array}{lr}\text { 7.5. Summary } & 186\end{array}$

8. How to Keep Languages Apart: Code-Switching and Code-Mixing

8.1. Code-Switching between Tariana and East Tucanoan Languages: Resistance to Dominance 
8.2. Code-Switching with Portuguese: Attitudes to 'White Man's' Language

8.3. 'They are Not Quite Like Us': Tariana and Baniwa 206

8.4. 'They Cannot Speak Properly': Mixing Tariana Dialects

8.5. Final Remarks: Semi-Speakers, Language Ideology, and the Status of English

9. Language Awareness and Correct Speech Among the Tariana

9.1. Morphemic Awareness 213

9.2. Phonological Awareness $\quad 2.15$

9.3. Morphosyntactic Awareness 216

9.4. Generational Awareness: 'This is How our Grandfathers Spoke'

9.5. Language Awareness and Status 220

10. Diffusion of Patterns and Direct Diffusion in the Vaupés

10.1. The Effects of Direct Diffusion from

East Tucanoan on Tariana

10.2. The East Tucanoan Effect on the Structure of the Tariana Lexicon

10.3. Independent Innovations in Tariana and Incomplete Convergence with East Tucanoan

10.4. Direct and Indirect Diffusion from East Tucanoan Languages

10.5. Diffusion in a Diglossic Situation

11. Language Obsolescence and Language Change in Tariana 243

11.1. Ilow Tariana Became Obsulescent 243

11.2. The Linguistic Consequences of Language Attrition 249

11.3. Levelling of Age Differences 259

11.4. Prospects for the Maintenance of Tariana 261

12. Language Contact in Multilingual Situations: Conclusions 265

12.1. Bilateral Diffusion without Dominance 266

12.2. Multilateral Diffusion without Dominance and Structural Convergence

12.3. Diffusion under the Newly Developed Dominance of Tucano, and Language Obsolescence

12.4. Diffusion in a Diglossic Situation: Tariana and Portuguese 
12.5. Diffusional Processes and Language Change: A

Comparison

Appendix 1. Classification of Arawak, Tucanoan, and Makú Languages; and a Grammatical Profile of Arawak I Languages

A1.1. Classification of Arawak, Tucanoan, and Makú Languages

A1.2. A Grammatical Profile of Arawak

Languages

A1.2.1. The common Arawak morphological nucleus

A1.2.2. Arawak languages north and south of the Amazon: difficulties with reconstructing Proto-Arawak

A1.2.3. The common Arawak lexicon

Appendix 2. Phonological Systems of North Arawak Languages of the Upper Rio Negro Area

Appendix 3. Arawak Languages North of the Amazon: Grammatical and Lexical Comparisons

Appendix 4. Portuguese of the Vaupés Area

Appendix 5. Language Proficiency among the Tariana of Santa Rosa

References

Index of Languages

Index of Authors

Subject Index 


\section{Preface}

This book is about how contact-induced changes can affect the grammars of gentetically unrelated languages. It is based on examples from Amazonia, with a special focus on the multilingual area of the Vaupés. The book can be used as a sourcebook for further in-depth studies on language contact, multilingualism, and sociolinguistic patterns acruss the world.

In order to understand language change, one needs to take account of various typological, historical-comparative, and sociolinguistic parameters. For this reason, the present volume spans several subfields within linguistics. Chapter 1 provides a general background; and Chapter 12 summarizes the findings. These are of interest to any linguist.

Readers interested in histurical and comparative studies and in language typology can concentrate just on Chapters 2 to 7, Chapter 10, and Appendices 1 to 3 . Those interested in how Portuguese, the national language of Brazil, affects indigenous languages, should read Chapter 7 . Appendix 4 will be of interest to those curious about the 'Portuguese of Indians', while 'pure' sociolinguists are advised to look at Chapters 8 and 9. Students of language obsolescence and language maintenance can focus on Chapter 11.

The synchronic approach is cast in terms of a cumulative typological framework of linguistic analysis-which employs 'the fundamental theoretical concepts that underlie all work in language description and change' (Dixon 1997: 128) and in terms of which significant typological generalizations are postulated; this has come to be called 'basic linguistic theory'. I have avoided employing any of the more specific formalisms (which conle and go with such frequency).

I have only been able to refer to a portion of the vast literature on language contact and related issues. There are many other sources that I have consulted but which are not referred to in this buok-either because they only provide additional exemplification of points that are already covered, or because they make claims not directly relevant to the topic, or because they concentrate on suggesting further models or 'paradigms' which are yet to be evaluated.

Detailed exemplification is provided for every point. English glosses are kept as close as possible to the glosses and explanations offered by my consultants. When no English equivalent is readily available, a Portuguese word is used, e.g. 'abiufruit' or 'mucura-rat'. Readers should be warned against trying to draw conclusions concerning the grammar and semantics of indigenous languages from the study of translations. 


\section{xiv Preface}

The orthography used in the examples from languages other than Tarianaincluding Portuguese-and language names follows that of the sources (unless indicated otherwisc).

It is my hope that this book will encourage linguists to go out into the field and describe contact situations involving languages threatened by extinction (before it is too late to do so), notwithstanding the difficulties and temporary frustrations which fieldwork necessarily entails. 


\section{Acknowledgements}

There are so many people to thank, it is hard to know where to begin.

My warmest thanks go to the Brito family who taught me the Tariana languagc and accepted me as a member of their household. I have been working on Tariana since 1991, when I met my first teacher, Graciliano Brito. I owe an immense amount of knowledge and experience to his brothers Ismael, Jovino, and José Luis, and to his sister Olívia. His father, Cândido Brito-one of the few traditional speakers and a real treasure-trove of Tariana lore and culture-was an indefatigable and patient teacher. His mother, Maria Sanchez-a Piratapuya herself-adopted me as her daughter and taught me quite a few secrets about the life of Vaupés women. Cândido's younger brother, Leonardo, was a great source of Tariana wisdom and lore. His elder son, Rafael, the youngest speaker of the Santa Rosa dialect, has always been most helpful, besides being great fun to have around. It is hard to find words to express my gratitude to this, my Tariana family.

I learnt a lot from all the other speakers of the Tariana dialect of Santa Rosa, who told me stories, or came to chat: Ricardo Brito, and his sons Emílio and Raimundo; José Manoel Brito and his children Sebastião, Cristiano, João, Clementina, and Joaninha; Juvenal, Abelardo, and their mother Amélia (a Wanano herself); Cristina, married to Abelardo; Jacinto Brito; and Batista Brito. Américo Brito, the oldest living speaker of Tariana, shared with me his eyewitness accounts of the offering feasts-he is the only living Tariana to have seen them. His eldest daughter Perfília deserves special appreciation for her warmth and openness.

The women in Santa Rosa made an effort to communicate with me and help me in many ways. Some spoke Tariana, like Cecília (Leonardo's wife, and my classificatory mother). With others, our language of communication was rudimentary Tucano and Portuguese. I am deeply grateful to Ednalúcia, Maria do Carmo, Clemência, Glória, Marília, Silvana, Terezinha, and Maurília. Feli Brito (Batista's son) knew no Tariana-I am grateful to him simply for being kind. And there are so many more people to thank-Eduardo Brito and his wife Antônia; Celeste Brito and Nestor Brito-for their hospitality and friendship.

Children of the Brito family were the most helpful, warm, curious, and delightful friends that one can imagine. My work would not have been completed without all kinds of help from Anastácia, Clarisse, Francileni, Francismar, Maria Esther, Maria Gracineidi, Nini, Vera Luz, and the youngest ones-Rosi, Juninho, Fátima, and many others.

My warmest gratitude also goes to the people of Periquitos, for teaching me their variety of Tariana, and for their perseverance in maintaining the language 
and speaking it to their children. I am grateful to the elders: Marino and Jorge Muniz; to the younger generation: Domingo, Gustavo, Ismael, Batista, Dário, and Dom Bosco; and to the women of Periquitos, who are quietly determined to save Tariana. The future of the language is in their hands!

I am deeply grateful to my teachers of Baniwa (Hohôdene and Siuci) and Kurripako-especially my sadly missed friend, the late Marcilia Rodrigues, and also to Afonso, Albino and Joao Fontes, Celestino da Silva, Cecília and Laureano da Silva. My gratitude goes to all those people from the Upper Rio Negro area who taught me their languages: Humberto Baltazar and Pedro Ângelo Tomas (Warekena); the late Candelário da Silva (Bare); the late Tiago Cardoso (Desano, Piratapuya), and also Alfredo Fontes (Tucano).

I would also like to acknowledge my debt to Padre Casimiro Bekšta, an expert on the area of the Upper Rio Negro and the Vaupés, who frequently helped with information and advice. He has been a real encyclopaedia of the Upper Rio Negro region for me since we first met in 1990. Paul Frank and Raul Zamponi supplied me with invaluable materials on the languages of the Upper Rio Negro. Ademir Ramos provided me with useful tips on the politics of the Upper Rio Negro. I have immensely profited from discussions with Elias Coelho, Lenita Coelho, Janet Barnes, Padre Jesús Arbella, Silvana and Valteir Martins, and also with Dominique Buchillet, Tim Curnow, Henri Ramirez, Camilo Robayo, Manoel Arroyo, Renato Atias, Marília Ferreira, and Stephen Hugh-Jones. Nara Barreto and Alan Baxter drew my attention to the unusual riches of the variety of Portuguese spoken in the Vaupés area.

I am grateful to all my ex-students and friends from Brazil, who accompanied me at the initial stages of fieldwork and provided friendship and support-Simoni Valadares, Tatiana Santos, Marcos Baltar, Antônio Augusto de Souza Melo, Cristiane Cunha de Oliveira, and especially Rute Maria Coelho.

This grammar would have been impossible without the assistance, support, and friendship of Silvana and Valteir Martins. Lenita and Elias Coelho, and their son Dani, provided a second home in São Gabriel da Cachoeira, looking after me, and giving me advice on every aspect of life, and concerning fieldwork in the remote areas of the Upper Rio Negro.

Warmest thanks go to Sisters Aline Sienkiewicz, Dária Moratelli, Cristina, Rita, and Ireni-who looked after me in so many different ways, making their mission welcoming for me-during my stays in Iauaretê. I am grateful to Dom Walter Ivan de Azevedo, the Bishop of the Upper Rio Negro, for constant support over the years.

All those who participated in the Tariana literacy class and helped organize it deserve separate thanks. Marta Azevedo provided us with the infrastructure and food; she also organized a pedagogical workshop which resulted in creation of quite a number of stories in Tariana. And without Glória da Silva, Cecília da Silva, Lourdes Brito, Galdino Pinheiro, Pedro Jesús, Jaquelene Brito, Vanilde Brito, Nestor Brito, and many, many others, this course would not have happened. 
Acknowledgements xvii

I am most grateful to those who read through the whole draft of this book, or parts of it, and provided comments, corrections and ideas-Alan Baxter, David Beck, Michael Clyne, Nick Enfield, Paul Frank, Alicc Gaby, Anthony Grant, Junia Schauer, Tonya Stebbins, Clay Strom, Catherine Travis, and Nathan Waltz. Invaluable comments on almost every page came from R. M. W. Dixon, without whose constant encuuragement and support I would have ncver completed this study.

I also owe thanks to Anya Woods, Publications Officer at the Research Centre for Linguistic Typology, who carefully checked the manuscript, and to Androw Hardie, who drew the Map.

I gratefully acknowledge the Wenner Gren Foundation for a grant which made my fieldwork financially feasible.

I had been planning to write a book on language contact in Amazonia for several years, but it was not until our Research Centre for Linguistic Typology relocated to the Institute of Advanced Study at La Tiube that I could complete the task. The Vice-Chancellor, Professor Michael Osborne, has been instrumental in creating a vibrant intellectual atmosphere within which the true business of scholarship may prosper. Last—but certainly not least—I am deeply grateful to him, our 'chicf' and patron. 


\section{List of Abbreviations}

\begin{tabular}{|c|c|c|c|}
\hline A & transitive subject & GEN & generic \\
\hline ADJ & adjective & GEN.ADJ & generic adjective \\
\hline$A D V$ & adverb & $\mathrm{HAB}$ & habitat \\
\hline ANIM & animate & HORT & hortative \\
\hline ANT & anterior & HUM & human \\
\hline ART & article & IMP & impersonal \\
\hline ASS & associative & IMPV & imperative \\
\hline ATTR & attributive & IMPV.SEC & secondhand imperative \\
\hline AUG & augmentative & INANIM & inanimate \\
\hline AUX & auxiliary & incl & inclusive \\
\hline CAUS & causative & INDF & indefinite \\
\hline CL & classifier & INFR & inferred \\
\hline COLL & collective & INS & instrumental \\
\hline $\mathrm{COM}$ & comitative & INTEN & intentional \\
\hline COMPL & completive & INTER & interrogative \\
\hline COND & conditional & INTR & intransitivizer \\
\hline CONV & converb & LIM & limiter \\
\hline DECL & declarative & LOC & locative \\
\hline DEF & definite & MASC, masc, m & masculine \\
\hline DEM & demonstrative & $\mathrm{NCL}$ & noun class \\
\hline DEP & dependency & NEG & negative \\
\hline DER & derivation & NEG.EXIST & negative existential \\
\hline DEVERB & deverbalizer & NOM & nominalization \\
\hline DIST & distal & NOM.LOC & locative nominalization \\
\hline DS & different subject & NOM.PAST & nominal past \\
\hline DUB & dubitative & NON1 & nonfirst person \\
\hline EMPH & emphatic & NONFEM, N.FEM, nf & nonfeminine \\
\hline excl & exclusive & NONPOSS & nonpossessed \\
\hline EXIST & existential & NONVIS & nonvisual \\
\hline FEM, F, f & feminine & NUM.CL & numeral classifier \\
\hline FOC.A/S & focused subject & $\mathrm{O}$ & direct object \\
\hline FR & frustrative & OBJ & object \\
\hline FUT & future & $\mathrm{p}$ & person \\
\hline FUT.CERT & certain future & PART & participle \\
\hline FUT.NOM & future nominalization & PART.CONTR & participant contrast \\
\hline FUT.UNCERT & uncertain future & PART.PAS & passive participle \\
\hline
\end{tabular}




\section{$\mathrm{xx} \quad$ List of Abbreviations}

$\begin{array}{llll}\text { PASS } & \text { passive } & \text { S } & \text { intransitive subject } \\ \text { PAUS } & \text { pausal } & \mathrm{S}_{\mathrm{a}} & \text { subject of an active intransitivise } \\ \text { PEJ } & \text { pejorative } & \text { SG, sg } & \text { singular } \\ \text { PERF } & \text { perfective } & \text { SIM } & \text { simultaneous } \\ \text { PL, pl } & \text { plural } & \text { SINGL } & \text { singulative } \\ \text { POS.ASS } & \text { positive assertive } & \mathrm{S}_{n} & \text { subject of a stative intransitive } \\ \text { POSS } & \text { possessive } & \text { SS } & \text { same subject } \\ \text { POT } & \text { potential } & \text { SUB } & \text { subordinator } \\ \text { PREC } & \text { precative } & \text { SUBJ } & \text { subjunctive } \\ \text { PRES } & \text { present } & \text { TH } & \text { thematic } \\ \text { PROB } & \text { probability } & \text { TOP.ADV } & \text { topic advancing voice } \\ \text { PROH } & \text { prohibitive } & \text { TOP.NON.A/S } & \text { topical nonsubject } \\ \text { PROX } & \text { proximate } & \text { VERB.COMPL } & \text { verbal complementizer } \\ \text { PURP } & \text { purposive } & \text { VERT } & \text { vertical } \\ \text { REC } & \text { reciprocal } & \text { VIS } & \text { visual } \\ \text { REC.P } & \text { recent past } & \text { VIS.EV } & \text { visual evidential } \\ \text { REFL } & \text { reflexive } & \text { VOC } & \text { vocative } \\ \text { REL } & \text { relative } & & \\ \text { REM.P } & \text { remote past } & & \\ \text { REP } & \text { reported } & & \end{array}$




\section{List of Tables and Figures}

\section{TABLES}

1.1. The Brazilian Vaupés: languages and their speakers 27

2.1. Vowels in East Tucanoan languages 35

2.2. A summary of consonants in East Tucanoan languages 35

2.3. Vowels in Tariana $\quad 35$

2.4. Consonants in Tariana 36

2.5. Phonetic realizations of independent pronouns in Tariana 49

2.6. Vowels in Retuarã and in Yucuna $\quad 55$

2.7. Consonants in Retuarã 56

2.8. Consonants in Yucuna 56

3.1. Persunal pronouns in Tucano, Wanano, and Desano 62

3.2. Cross-referencing prefixes and personal pronouns in Tariana
(compared to Baniwa and to Proto-Arawak)

3.3. Proto-Tucanoan and Proto-Arawak: a comparison 65

3.4. Cross-referencing prefixes in Retuarã and in Yucuna 73

3.5. Contact-induced changes in Tucanoan languages, compared with
Common Nurth Arawak

3.6. Contact-induced changes in Arawak languages, compared with $\begin{array}{ll}\text { Proto-Tucanoan } & 75 \\ & 78\end{array}$

4.1. Possession marking in Tucanoan and in Arawak languages 78

4.2. Possession marking in Baniwa, Tariana, and Tucano 85

4.3. East Tucanoan areal impact on Tariana classifiers 88

4.4. Number values for inanimates in Tucano and in Tariana 97

4.5. Grammatical relations in Tariana, Tucano, and Baniwa 102

4.6. Marking of grammatical functions in Tariana and in Tucano 102

4.7. Oblique cases in Baniwa, Tariana, and Tucano 101

4.8. Numbers 'four' and 'five' in Baniwa, Tariana, and Tucano 108

4.9. Demonstratives in Baniwa, Tariana, and Tucano 108

5.1. Evidentials, tense, and person in Tucano and in Tariana 120

5.2. Person, gender, and number prefixes in Tariana 120

5.3. Subsystems of evidentials in Tariana and Tucano depending on

5.4. Aktionsart enclitics with corresponding verbs in Tariana 137

$\begin{array}{ll}\text { 5.5. Diffusion of predicate categories } & 149\end{array}$

6.1. Switch-reference enclitics in Tariana 159

9.1. Areally diffused patterns and morphosyntactic awareness 217

9.2. Generational differences between Tariana speakers: a sample 218 
xxii List of Tables and Figures

10.1. Case marking in Tariana and in East Tucanoan

10.2. Reciprocal, emphatic and reflexive meanings in Baniwa, Tariana, Tucano, and Desano

11.1. Reduction of the traditional multilingualism in the Tariana community of Santa Rosa

11.2. From multilingualism to monolingualism: Rodenäs 246

12.1. Four situations of language contact: a comparison 277

\section{Appendix 1}

A1.1. Arawak languages 282

A1.2. The Tucanoan language family 286

A1.3. The Makú languages 287

A1.4. Proto-Arawak A/S $\mathrm{S}_{\mathrm{a}} /$ possessor prefixes and $\mathrm{O} / \mathrm{S}_{\odot}$

A1.5. Cross-referencing prefixes in Bare 289

A1.6. Cross-referencing prefixes and enclitics in Warekena 290

A1.7. Valency-changing affixes in Arawak languages and elsewhere 293

A1.8. Predicate structure in South Arawak and North Arawak 294

\section{Appendix 2}

A2.1. Consonants of Baniwa of Içana/Kurripako 297

A2.2. Vowels of Baniwa of Içana/Kurripakn 297

A2.3. Consonants of Piapoco 298

A2.4. Vowels of Piapoco 298

A2.5. Consonants of Guarequena 299

A2.6. Vowels of Guarequena 299

A2.7. Consonants of Achagua 300

A2.8. Vowels of Achagua 300

A2.9. Consonants of Warekena of Xié 301

A2.10. Vowels of Warekena of Xié 301

A2.11. Consonants of Bare 302

A2.12. Vowels of Bare 302

\section{Appendix 3}

A3.1. Shared vocabulary percentages between selected Arawak languages 304

A3.2. Cross-referencing in North Arawak languages 305

A3.3. Distribution of Arawak grammatical properties in North Arawak languages

A3.4. Classifier types in North Arawak 307 
A3.5. Number of cognates in classifiers in North Arawak 307

A3.6. Number of cognates in case markers 308

A3.7. Negation marking in North Arawak 310

A3.8. Evidentiality meanings and marking in North Arawak 310

Appendix 5

A5.1. Evaluation of speakers' proficiency 319

A5.2. Language proficiency among the Tariana and their spouses 320

FIGURES

1.1. Marriage possibilities between language groups in the Vaupés area

5.1. Evidentials in question-response: Tariana and East Tucanoan 


\section{List of Plates}

\section{Between pp. 198-99}

Plate 1 Departing from São Gabriel.

Plate 2 Arrival in Santa Rosa.

Plate 3 The Tariana of Santa Rosa.

Plate 4 The Tariana of Periquitos.

Plate 5 Working in Olívia Brito's house in Iauaretê.

Plate 6 The role of Portuguese in the life of Iauaretê.

Plate 7 Members of the Brito family in front of the Cultural Centre in Iauaretê.

Plate 8 Heated discussion in Olívia Brito's house.

Plate 9 Cândido Brito, keeper of the old Tariana.

Plate 10 Maria Sanchez, the wife of Cândido Brito, a Piratapuya.

Plate 11 José Luis Brito, the author, and Rafael Brito teaching the Tariana language course.

Plate 12 José Luis Brito teaching a little girl how to pronounce Tariana sounds.

Plate 13 The Tariana language course.

Plate 14 Emílio Brito, one of the most dedicated teachers.

Plate 15 Marino Muniz, José Luis Brito, and Ismael Muniz trying to sort out the dialectal differences during the Tariana language course.

Plate 16 The Tariana of Periquitos working out the most appropriate orthography for their language. 


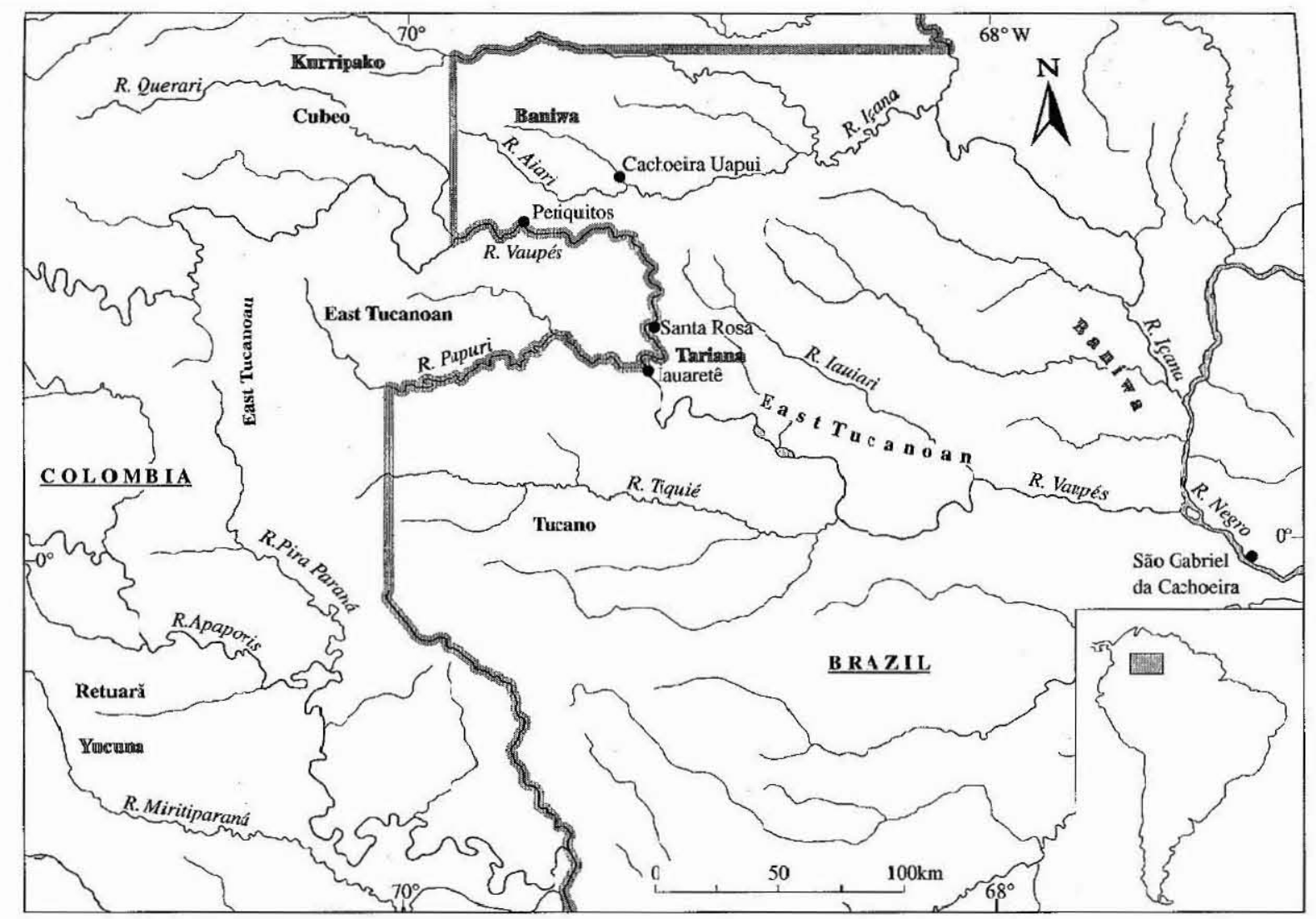

MAP. Arawak and Tucanoan langucges in north-western Amazonia. Names of Tucanoan languages are in black, while names of Arawak languages are in grey. 


\section{Language Contact and Language Change in Amazonia}

\subsection{What this Book is About}

Languages can resemble each other in the categories, constructions, and types of meaning they use; and in the forms they employ to express them. These similarities may be due to universal properties-for instance, all languages have clausal negation. Sometimes two languages can share the same form by pure coincidence-the Korean word for 'two', pronounced as [du], bears a chance similarity to Latin duo 'two' (cf. Aikhenvald and Dixon 2001: 1-2). Similarities of these kinds tell us nothing about the history of languages. The really significant similarities are those due to shared origin or to language contact.

If two modern languages descend from a common ancestor, both may retain features of this shared 'proto-language'. Their similarities are then due to genetic inheritance. In addition, genetically related languages often develop along similar lines-this is called 'parallelism in drift' by Sapir (1921: 147-70).

If languages are in contact, with many speakers of one language having some knowledge of the other, then they typically borrow linguistic features back and forth-habits of pronunciation, significant sounds (phonemes), grammatical categories, vocabulary items, and even some grammatical forms. Borrowing may extend over all or most of the languages in a geographical region. We then find large-scale linguistic diffusion. defining the region as a 'linguistic area' (see $\$ 1.2 .2$ below).

Languages in contact-where a significant proportion of the speakers of one also have some competence in the other-gradually become more like each other. This is known as convergence (see \$1.2.1). The most pervasive borrowing generally involves construction types, grammatical categories, and the organization of lexical and grammatical meanings. There can also, of course, be borrowing of lexical forms and-to a lesser extent - of grammatical forms. The extent of this varies from culture to culture. One Arawak language, Tariana, has a prohibition against borrowing forms from its neighbours, while Resígaro-another Arawak language spoken in a different region-borrows them freely (see Aikhenvald $2001 b$ ).

One of the hardest tasks in comparative linguistics is to distinguish between similarities due to genetic inheritance and those due to borrowing. It is undoubtedly the case that some features are particularly open to--and others are particularly resistant to-diffusion. 


\section{1. Language Contact and Language Change in Amazonia}

Only in-depth studies, based on first-hand data, will enable us to formulate sensible inductive generalizations concerning the ways in which genetically unrelated or distantly rclated languages becomc similar duc to prolonged contact, multilingualism, and borrowing. Such studies have been accomplished for just a few places in the world-the Balkan linguistic area (e.g. Joseph 1983; Friedman 1997 and references therein), India (e.g. Emeneau 1980; Masica 1976), the East Arnhem Land and the Daly River regions in Australia (Heath 1978; Dixon 2002). No such studies have yet been provided for Amazonian languages.

The Amazon basin is an area of great linguistic diversity and one of the least known regions of the world linguistically. It comprises around 300 languages grouped into over 15 language families, plus a fair number of isolates. The six major linguistic families of the Amazon basin are Arawak, Tupí, Carib, Pano, Tucano, and Jê; smaller families include Makú, Bora-Witoto, Harakmbet, Arawá, Chapacura, Nambiquara, Guahibo and Yanomami. (Various macro-groupings or 'stocks' have been suggested, by Greenberg and others; these are, almost without exception, illusory and otiose. ${ }^{1}$ )

All the major language families are highly discontinuous. For instance, Arawak languages are spoken in over ten locations north of the Amazon, and in over ten south of the Amazon. The language map of Amazonia thus resembles a patchwork quilt where over a dozen colours appear to be interspersed at random. Frequent migrations and language contact bring about extensive borrowing and grammatical change, restructuring the grammar in agreement with areally spread patterns, reanalysing existing morphemes, and introducing new morphology (often by grammaticalizing lexical items). This produces a linguistic situation unlike those found in most other parts of the world, creating difficulties for distinguishing between similarities due to genetic retention and those due to areal diffusion.

The raison d'être of this book is to provide a systematic analysis of contactinduced language change between two reasonably well-documented, genetically unrelated and typologically different language families north of the AmazonNorth Arawak and Tucanoan. I will concentrate on different language contact patterns in the multilingual area of the Vaupés basin, comparing them with other known instances of Arawak-Tucanoan contacts. All of these contact situations share a strong tendency to keep languages strictly apart by restricting the influx of borrowed forms. This creates an almost ideal 'linguistic laboratory' for investigating diffusion of patterns rather than of forms.

1 Until recently, classifications of South American languages have been almost exclusively the work of scholars who had little first-hand knowledge of the languages involved. Loukotka (1968) and Tovar and Tovar (1984) are now somewhat outdated, but on the whole reliable. Kaufman's (1990) classification was flawed; it has been uncritically followed by Campbell (1997), but contains numerous factual errors (a similar classification is found in Migliazza and Campbell 1988). See Aikhenvald $2002 a$, for details. Dixon and. Aikhenvald (1999) (drawing on the expertise of scholars familiar with the individual language families) can be regarded as a state-of-the-art classification: see Appendix 1. 


\subsection{Linguistic Diffusion and Grammatical Borrowing}

In $\S 1.2$ I discuss general issues of language contact and language change and provide a working definition of a linguistic area. The known instances of ArawakTucanoan language contact are overviewed in $\$ 1.3$. Then, in $\$ 1.4$, I consider the linguistic situation in the multilingual Vaupés area. The materials on which my study is based are discussed in $\S 1.5$. The last section, $\S 1.6$, describes the organization of the remainder of this book.

\subsection{Linguistic Diffusion and Grammatical Borrowing}

An examination of the diffusion of linguistic features between genetically unrelated and typologically different languages in varied situations of language contact allows us to determine tendencies and preferences in contact-induced grammatical change (though this does not necessarily involve establishing straightforward 'hierarchies' of borrowability).

Languages reflect the sociolinguistic history of their speakers; and language attitudes, as well as relationships between languages within a contact situation, influence the outcome of language contact. It is hard to wholeheartedly agree with the basic starting-point in I'homason and Kaufman (1988: 35), that 'it is the sociolinguistic history of the speakers, and not the structure of their language, that is the primary determinant of the linguistic outcome of language contact.' Typologically different linguistic structures tend to change in different ways, ${ }^{2}$ even when the speakers share a great deal of sociolinguistic history. In Chapter 3 we will see how East Tucanoan languages and Tariana, an Arawak language-all spoken in the same environment and the same sociolinguistic conditions-have changed in strikingly different ways.

In the situation of stable multilingualism and constant interaction between languages, one expects the gradual development of structural compatibility; that is, 'convergence' in terms of categories and the slots in which they are marked. Throughout this book we will see how changes of different sorts operate in phonology, morphology, syntax, and discourse. In what follows, I describe the types of language change (\$1.2.1), introduce the notion of linguistic area (\$1.2.2), enumerate the sociolinguistic parameters relevant for language contact (\$1.2.3), and discuss what is likely to be borrowed (\$1.2.4).

\subsubsection{Types of linguistic change}

Before we proceed, a few terminological remarks are in order. BORROwING is used here in a broad sense, as 'the transfer of linguistic features of any kind from one language to another as the result of contact' (Trask 2000: 44). Both CODESWITCHING and CODE-MIXING involve 'the alternative use of two languages either

\footnotetext{
${ }^{2}$ For this reason, even Thomason and Kautman (1988) often refer to notions such as 'typological distance' between languages.
} 


\section{1. Language Contact and Language Change in Amazonia}

within a sentence or between sentences' (Clyne 1987: 740). I follow the differentiation made by Hill and Hill (1986: 348), 'between meaningful and appropriate code-switching [i.e. which follows established conventions and practices] and disorderly usage of the type which has been called "code-mixing"' (cf. a similar definition in Trask 2000: 61).

I employ the term INTERFERENCE in the sense of 'the non-deliberate carrying of linguistic features from one's first language into one's second language' (Trask 2000: 169). Interference is thus more restricted than borrowing and is mainly applicable to second-language acquisition (cf. Curnow 2001).

DIFFUSION is understood as the spread of a linguistic feature across a geographical area (cf. Trask 2000: 91) or as borrowing within a LINGUISTIC AREA. Diffusion can he unilateral (from one source) or multilateral (from several sources).

I distinguish between DIRECT DIFFUSION-that is, diffusion, or borrowing of forms (in the broad sense of this term) - and INDIRECT DIFFUSION—diffusion or borrowing of categories, or of terms within a category (sometimes also called 'transfer of patterns': cf. Heath 1978). For instance, a language can develop a system of noun classes, switch-reference, or evidentiality out of its own formal resources, to match the existing categories in a contact language. Direct and indirect diffusion may involve simultaneous gain (of new morphemes and patterns) and loss (of old morphemes and patterns). Or it may involve creating new patterns which cnexist with the old ones, together with new rules for the distribution of old patterns.

The latter is comparable to the creation of etymological doublets, i.e. several words in a language which have been borrowed at different times from the same item in a single source, e.g. English chief and chef; or pairs of almost-synonyms, one of which is borrowed and the other one inherited, e.g. English chef and cook.

The distinction hetween diffusion of forms and diffusion of patterns is crucial, since linguistic communities differ with respect to their acceptance of loan forms. Some adopt loan forms on a large scale, while others consider using 'foreign' importations as tnkens of unacceptable language-mixing. We will see examples of this below.

I distinguish the following types of contact-induced change (besides direct diffusion of forms):

(a) SYSTEM-ALTERING CHANGES involve the introduction of new categories-by analogy with other language(s) in the area-and restructuring of existing categories. Examples of such a system-altering change include the development of core case marking in Tariana, under the influence of East Tucanoan languages (see Chapter 4); and the restructuring of the case system in Ardeşen Laz under Turkish influence (Haig 2001: 214-17)

(b) SYSTEM-PRESERVING CHANGES do not involve any new categories; they may add a new term to an already existing category; or grammaticalize a morpheme to preserve threatened functional categories (Heath's 1997 and 1998 'lost wax' and 'hermit crab'; see also discussion in Watkins 2001: 59-60). For instance, 
Resígaro-an Arawak language spoken in Peru which originally had a fairsized classifier system - has extensively borrowed additional classifiers from the neighbouring Bora-Witoto languages (Aikhenvald 2001b).

Additional types of change are:

(c) LEXICAL ACCOMMODATION, which involves adaptation of existing lexical roots in the language to those which are similar and possibly even cognate in the source contact language ('diffusing' language). This is comparable to what Haugen (1969) has called 'homophonous extensions' - that is, formations which resemble a model phonetically but not necessarily semantically, e.g. Norwegian American brand 'bran' (meaning in Standard Norwegian: 'fire') which acquired its new meaning under the influence of English bran.

(d) GRAMMATICAL ACCOMMODATION involves morphosyntactic deplnyment of a native morpheme on the model of the syntactic function of a phonetically similar morpheme in the diffusing language. This can be exemplified by the influence of the Ilittite imperfective marker -ske- on Eastern Ionic Greek (as described hy Watkins 2001: 58): as a result, the homophonous Greek morpheme acquired an imperfective meaning. Examples of similar extensions of (unrelated) Tariana morphemes under Tucano influence in the Vaupés are discussed in $\$ 10.1$.

In a language contact situation with dominance relationships (\$1.2.3), accommodations can be viewed as a compromise between resistance against borrowed forms, and growing pressure from the dominant language.

Structural changes vary as to their stability. Following Tsitsipis (1998: 34), I divide grammatical changes into COMPLETED, ON-GOING (or CONTINUOUS), and DisCONTINUOUS. Completed changes cover those aspects of the grammatical system of a language which do not show any synchronic variation and which go beyond speakers' awareness. On-going or continuous changes are those in progress; here the degree of influence of the other language depends on the speaker's competence and possibly other, sociolinguistic, variables (such as age or degree of participation in community life). Discontinuous changes are one-off deviations characteristic of individual speakers. In the situation of language attrition these often differentiate fluent speakers from less proficient ones.

This classification of changes is particularly important for distinguishing between old and established diffusional processes-characterized by completed changes—and new, in-coming, continuous changes; see $\$ 1.3$.

Borrowing grammatical categories may involve:

(i) 'Wholesale' borrowing of a grammatical system. When this happens, either some existing system may become reanalysed and restructured; or a new system may be invented, e.g. grammaticalized from independent lexemes in the target language (this may go together with the borrowing of some grammatical morphemes). An example of this is the development of obligatory evidentiality distinctions in Tariana, under influence from East Tucanoan languages (see Chapter 5). The opposite of this would be a 'wholesale' loss of a system. 
(ii) Adding a term to the existing system. For instance, if one language has a number system consisting of singular and non-singular and a neighbour has singular, dual, and plural, the first language may innovate a dual. This happened in Resígaro, under the influence of the neighbouring Bora-see Aikhenvald (2001b). The opposite of this would be loss of a term.

(iii) Borrowing of proccsscs, c.g. doublc marking of plural or of case in a word, or borrowing of phonological processes: see Chapters 2 to 4 for some examples.

(iv) Borrowing of syntactic constructions, such as clause types; or discourse tcchniques: numcrous cxamples of this are given in Chapter 6.

The result of language contact can be language attrition, obsolescence, and shift to another language. Alternatively, language contact may bring about gradual convergence resulting in structural isomorphism, whereby the grammar and semantics of one language are almost fully replicated in another (cf. Gumperz and Wilson 1971; Nadkarni 1975; Friedman 1997; this is sometimes termed metatypy: Ross 2001). This concept of convergence may involve at least three kinds of processes:

(a) Convergence can result in the adoption of new patterns by all the languages involved. New patterns coexist with the old ones; and new rules for their distribution are developed. (This is comparable to the creation of etymological doublets mentioned above.) The isomorphism of grammatical structures is not complete since each language preserves its own 'typological profile', alongside the adoption of a 'foreign' one.

(b) Alternatively, convergence can result in creating a new common grammar, which combines features of both systems in contact-a compromise between the structures. Grammatical isomorphism may tend to be strong (but not complete).

Convergence of types (a) and (b) presupposes the lack of any relationships of dominance or diglossia between the languages in contact (see \$1.2.3). The necessary condition for convergence of type (c) is a relationship of dominance between languages.

(c) Convergence can also involve the adoption of the structure of the source language and concomitant loss of categories which have no equivalent in the target language. This kind of convergence involves loss of patterns and is often accompanied by the attrition and obsolescence of the 'minority' language. It may result in morpheme-for-morpheme intertranslatability between the languages in contact (unless the minority language ceases to be spoken).

System-altering changes and wholesale borrowing of grammatical systems on the way to convergence can result in the restructuring of languages in contact. For instance, a head-marking language can acquire dependenl-marking properties; a suffixing language may acquire prefixes (and lose suffixes); or an active-stative language may acquire nominative-accusative properties.

The very idea of such restructuring and concomitant system-altering changes goes against the oft-quoted 'structural compatibility requirement'. In its strong 
form, this requirement states that borrowing can operate only between similar systems (see, among many others, Meillet 1914: 84, 87; Moravcsik 1978; Weinreich 1953: 25). This claim holds only as a tendency (as demonstrated by IIarris and Campbell 1995, and Haig 2001). But if it holds at all, the question arises: how do the languages come to be structurally similar in the first place? These three types of convergence provide an answer.

In neither of the three cases do the grammars of languages in contact become fully identical. Convergence between linguistic structures is most frequently incomplete. Soper (1996: 287), in his seminal study of intensive Turkic-Iranian contact, pointed out that all languages in contact "exhibit departures from the grammatical structures of the donor-languages'. If one language dominates over the other, cunvergence may potentially involve full isomorphism and adoption of the other language's structure at the expense of one's own. But the minority language often ceases to be spoken before a full convergence is achieved.

The net results of language contact are often measured in terms of 'loss' (deterioration, impoverishment, or simplification-cf. Gomez-Imbert 1996) or 'gain' (that is, enrichment) of patterns. The degrees of 'gain' and 'loss' differ depending on a conlacl situation. We return to this in \$1.2.4.

From the point of view of its time-frame, contact can be continuing at presentas in the case of the languages in the Vaupés area, in Mesoamerica, in the Balkans, in East Arnhen Land, and so on. Or it could have taken place in the past-then its effects survive in the form of completed diffusional phenomena; but there is little current interaction (or bilingualism). This is the case of Yucuna (Arawak) and Reluarã (Central Tucauoan) (\$1.3), or Takia (Austronesian) and Waskia (nonAustronesian) on Karkar island in Papua New Guinea (see Ross 2001). In none of these cases is there reason to believe that contact-induced changes were triggered by a language shift; consequently, the changes cannot be explained by 'imperfect learning' of a foreign language, or by speaking it with a foreign accent (cf. Chapter 2); they are due to language-internal developments not related to these factors.

Language shift has been documented in other instances: for example, a number of Cubeo-speaking clans are known to have recently adopted Cubeo (Central Tucanoan), having shifted from a North Arawak language similar to Baniwa (this is known from Cubeo oral histories: see Goldman 1979; Gomez-Imbert 1996: $445-7$, and $\S 1.3$ ).

The actual mechanisms of contact between languages interact with various sociolinguistic variables—see $\S 1.2 .3$.

\subsubsection{Linguistic areas}

The concept of a LINGUISTIC AREA is central to the notion of diffusion. A linguistic area (or Sprachbund) is generally taken to be a geographically delimited area including languages from two or more language families, sharing significant traits 
(most of which are not found in languages from these families spoken outside the area). There must be a fair number of common traits and they should be reasonably distinctive (also sec definitions by Emencau 1956; Sherzer 1973: 760; and discussion in Tosco 2000).

The main problem is how to locate the diagnostic traits, especially when at least some shared featurcs-or similaritics-between contiguous languages can be explained by accident, universals, genetic factors (that is, if languages in contact are related), etc. As shown in the masterly study of Mesoamerica as a linguistic area by Campbcll, Kaufman, and Smith-Stark (1986: 535), not all shared features have the same 'weight', since "highly "marked" exotic, or unique shared traits weigh more than does material that is more easily developed independently, or found widcly in other languagcs'. Since 'mcaningful linguistic areas are the historical products of linguistic diffusion, the stronger linguistic areas are those whose shared traits can be shown to be diffused - and cannot be ascribed to a common ancestor, to chancc, or to universals' (p. 536).

The problems with establishing genetically inherited vs. diffusional features in North-American Indian languages north of Mexico have been analysed in Sherzer (1976) and Bright and Sherzer (1976); for Australia, problems of this kind have been analysed by Dixon (2002). If borrowing is facilitated by 'the pre-existing similarity of structure', the two types of similarities can be hard to disentangle (see Smith 1986, on Kugu Muminh). For this purpose, a fine-grained reconstruction at the level of individual subgroupings is needed, as is the case with Indo-European languages in the Balkan linguistic area. Otherwise one would never be able to go beyond just saying that 'Sprachbund situations are notoriously messy' (Thomason and Kaufman 1988: 95).

Linguistic areas may involve unilateral or multilateral diffusion. In each case, the source of diffusion can be cstablished if we have access to the relevant synchronic data and linguistic reconstructions. Chapters 2 to 6 of this book illustrate this for the Arawak and Tucanoan languages spoken in the Vaupés linguistic area, in north-western Amazonia.

When closely related languages are in constant contact, additional complications arise (see \$1.3). Teasing apart the effects of diffusion, genetically inherited phenomena, and the possible outcomcs of parallel devclopment (sce §1.1) may become a daunting, almost impossible task. Languages which have never been in contact or never formed a linguistic area can share diffused properties if they have borrowed the features independently from the same or a similar source. This was probably the case for numerous Ethio-Semitic languages which share similar features, taken from a shared Cushitic substratum (Tosco 2000). Comparative analysis of the Arawak languages of the Vaupćs with Bora-Witoto (north-eastern Peru) and with Tucanoan reveals their striking similarities - but in this case the lack of historical information makes it difficult to decide whether the similarities are due to intensive areal diffusion or to sharcd substrata. 


\subsection{Linguistic Diffusion and Grammatical Borrowing}

In most linguistic areas, speakers of all languages share cultural traits. However, shared culture does not imply the existence of a linguistic area. A necessary condition for a linguistic area is some degree of bi- and/or multilingualism. The Great Plains in North America has been recognized as a cultural area, but not as a linguistic area-the languages of the area have not had long enough time to develop areal traits (Sherzer 1973; Bright and Sherzer 1976: 235). Bilingualism was almost non-existent there (Douglas Parks, personal communication). Another example of a cultural area which has not yet become a linguistic area is the Upper Xingu in Brazil (see Seki 1999: 428). Linguistic areas can be incipient, young, or old. Their age and stability depend on the relationships between languages—-see $§ 1.2 .3$.

\subsubsection{Sociolinguistic parameters in language contact}

The outcomes of language contact may depend on a large number of variables (see Aikhenvald and Dixon 2001; Ross 2001; Andersen 1988). Hierarchies of prestige groups (castes, etc.) and relations of dominance (social and/or political) between languages or dialects are known to influence the direction of borrowing and diffusion. There is, typically, borrowing from a prestige into a non-prestige language, e.g. from Turkish into the variety of Greek spoken in Asia Minor. A growing relationship of dominance may result in the attrition of what becomes a minority language. This situation has been described as 'linguistic stress' by Silva-Corvalán (1995). Alternatively, languages in contact may have equal status. The linguistic outcome of this 'peaceful coexistence' is generally different from that where there is a dominance relationship.

Relationships between languages can involve diglossia (in the sense of Ferguson 1964; see also Fishman 1967 and a summary by Schiffrin 1998). Diglossic language situations are characterized as involving two (or more) varieties that coexist in a speech community, in a kind of complementary distribution between the domains of usage. Contrary to Fishman (1967), stable multilingual situations do not necessarily require diglossic relationships between languages, especially in the case of traditional multilingualism (cf. Appel and Muysken 1987: 5, and also Smith 1986; Aikhenvald 1996a, and many others).

Multilateral linguistic areas may differ in terms of the relationships between the languages. We hypothesize that linguistic areas which arose as the result of equilibrium situations (in the sense of Dixon 1997) involve long-term language contact with multilateral diffusion and without any developed relationships of dominance. In contrast, areas which were formed as a result of sudden migrations or other punctuations tend to involve dominance of one group over other(s) (though not necessarily across the whole area), and the diffusion is often unilateral.

Linguistic areas can be relatively young or relatively old. (Note that once we attempt to go back in time before the advent of written records, any kind of linguistic dating must, by its nature, be speculative.) In the Vaupés region of Amazonia, Tariana and East Tucanoan languages appear to have been in contact 
for at least a few hundred years. Other known linguistic areas of the world-e.g. the Balkans, East Arnhem Land in northern Australia (see Heath 1978), Mesoamerica (Campbell et al. 1986), South Asia (Masica 1976), and linguistic areas for North-American Indian languages north of Mexico (Sherzer 1976), such as the north-western coast (Bright and Sherzer 1976: 234; Thompson and Kinkade 1990 ) - could be older than this. The defining features of Standard Average European $^{3}$ seem to have been in place by the end of the first millennium CE, while their formation in individual languages is hypothesized to go back several centuries earlier. Some of these features were diffused from individual languages that had developed them earlier, while other features are likely to have arisen after this area had already been formed (see details in Haspelmath 1998). Urdu, Marathi, and Kannada had coexisted in the multilingual village of Kupwar in India for about three or four centuries when the Urdu-speaking Muslims arrived in the region (Gumperz and Wilson 1971: 153). This is an area with advanced structural isomorphism (and occasional loans of morphemes). Kannada-speaking and Marathi-speaking people are known to have been in the region for more than six centuries, so their interaction could be older. We have no real idea how long it may take for a linguistic area to be established. Depending on various types of factors it could take a few hundred years or a few thousand years-as must have been the case for India as a linguistic area (Masica 1991: 37). But the existing evidence suggests that strong convergence of structure is most likely to involve a time-span of more than a mere couple of hundred years.

A linguistic area created under an equilibrium situation would typically lack any dominance relations, and would, as a consequence, be long-lasting. In the event of a punctuation-which is often accompanied by a growing relationship of dominance of one group over another-an area would not endure. As a result of intensive contact, one language and its structure simply 'wins' over another; the minor languages fall into disuse and die. In each case we need to know the social conditioning of an area, especially in relation to language attitudes and dominance relationships.

Crucial factors in understanding types of language contact are whether there is multilingualism or simply bilingualism, involving what proportion of the community, and which social groups, are involved. One expects more extensive grammatical borrowing in a situation of stable well-established multilingualismas in the Vaupés (see \$1.4). The choice of which language to use may depend on the social situation (this is diglossia, where-for example - one language, or dialect, may be used in the home and in religious observances, and another in all other circumstances) or on the individual (each person will speak his or ther own first language, but be able to understand other languages used in the community). Different degrees of 'lingualism' can be connected to cultural practices,

\footnotetext{
3 Standard Average European-also known as the European Sprachbund-is a linguistic area which includes Germanic, Romance, and Slavic languages, as well as the languages of the Balkans (see the detailed discussion in Haspelmath 2001: 53-5).
} 
such as intermarriage. In the Vaupés linguistic area, obligatory multilingualism is 'conditioned' by obligatory exogamy ( $\$ 1.4)$. Such obligatory multilingualism based on linguistic exogamy (one must marry someone from a different language group) is rare, but not unique. The same principle is at work in the Wik-speaking areas of the Cape York Peninsula, in northern Australia (Peter Sutton, personal cummunication; see also Sutton 1978), and possibly in other areas of northern Australia (see Rigsby 1997, for some linguistic aspects of areal diffusion there).

Attitudes towards non-native languages may vary, both between communities and within a given community. Speakers of Athapaskan languages preferred not to accept loanwords from the languages with which they had contact but would instead create names for new objects and ideas from their own lexical and grammatical resources (see the insightful discussion of lexical acculturation in Brown 1999). This also relates to questions of language planning (as when Kemal Atatürk resolved to rid Turkish of its Arabic loans-some of fair antiquityreplacing them with native coinings). At the opposite extreme, there has been a forceful introduction of foreign elements from Chinese into the minority languages of China in order to 'improve' them (Matisoff 1991); and Pontius (1997) shows that social enmities (as in the case of Czech and German) can create an obstacle to structural borrowings. Borrowings of forms from other indigenous languages are condemned as culturally inappropriate in the Vaupés area.

Thesc parameters are not exhaustive, but they are the ones that will prove useful for our investigation of various patterns of language contact in the Amazonian region. Other potentially important variables include the lifestyle of speakers (e.g. whcther nomadic hunter-gatherers, village-dwelling agriculturalists, nomadic cattle herders, or largely urbanized groups); the division of labour between sexes and between generations; social organization and the kinship system; and religion and mythology.

\subsubsection{Which linguistic features are likely to be borrowed?}

The question of what can and what cannot be borrowed has been the focus of studies of language contact since Whitney (1881). Various hierarchies of borrowing and constraints on borrowability have been suggested (e.g. Weinreich 1953; Moravcsik 1978; see a summary in Wilkins 1996, and also Matras 1998). None of them appears to hold as universal (cf. Harris and Campbell 1995: chap. 6; and Aikhenvald 2006). As Curnow (2001: 412) puts it 'the one definite conclusion which almost every examination of language contact has inevitably come to is that expressed by Thomason and Kaufman (1988: 14)', that 'as far as strictly linguistic possibilities go, any linguistic features can be transferred from any language to any other language'. ${ }^{4}$

\footnotetext{
4 Along similar lines, Matisoff (1991: 447) pessimistically suggests 'we must content ourselves with sitting back and watching how languages change syntactically and semanticaliy accurding to their own inner, inscrutable laws'.
} 


\section{1. Language Contact and Language Change in Amazonia}

Ilowever, the failure to establish an overarching hierarchy of borrowability does not necessarily imply the absence of valid tendencies and preferences in linguistic diffusion. These do exist (cf. for instance the incisive analysis by Ileath 1978: 105-15). And they appear to be conditioned by the structure of the languages under consideration and by various sociolinguistic parameters. Many more in-depth case-studies are needed before we will be able to formulate useful generalizations concening universal tendencies on borrowability. To discover which linguistic features tend to be borrowed in varied language contact situations in Amazonia is another aim of this book (gencralizations based on further case-studies can be found in Aikhenvald 2006).

To work out preferences and tendencies in linguistic diffusion, it is necessary to concentrate on the following questions.

1. What units are 'borrowed' or 'diffused' in language contact? In the case of convergence, what types of unit are acquiring a similar, or a typologically compatible structure? To answer this question, we will investigate the diffusional phenomena at the level of phonemes, phonological and grammatical words, morpheme structure, clauses, sentences, and paragraphs (understood as larger discourse units).

2. A great many scholars have suggested (Stolz and Stolz 1996; Matras 1998; IIaig 2001) that the 'direction' of borrowings proceeds 'from top to bottom', starting from larger discourse units, and clause coordination and subordination mechanisms, then extending to smaller syntactic units, and finally to morphology. The isomorphism in discourse linking-and clause subordination and coordination-between different languages of modern East Anatolia has been demonstrated by Haig (2001). This conclusion is corroborated by numerous studies of syntactic borrowings (see, for instance, Juhanson 1998, for Irano-Turkic contacts). The discourse frequency of certain morphemes can also be conducive to their high borrowability (see Aikhenvald $2001 \mathrm{~b}$, on borrowed classifiers in Resígaro). The same principle accounts fur the frequency of borrowing constituent order (not necessarily accompanied by borrowing word order within individual constituents), or 'surface linear order of constituents' (Haig 2001: 218), in an attempt to match the infoimation structure of the source language in the target language. Explicit markers of syntactic linkage - clause and noun phrase connectives - are also highly favoured in borrowing, as is expressive morphology (scc Haig 2001; Matras 1998 and Chapter 10 beluw).

3. Can the impact of direct diffusion differ from that of indirect diffusion with respect to the types of changes and types of convergence involved? We will sec that in the Vaupés area indirect diffusion results in the emergence of new categories through reanalysis of existing grammatical patterns and through grammaticalization processes. The existing (albeit very limited) direct diffusion results just in adding another term to an already existing category. Whether or not 
the grammatical behaviour of a morpheme in the target language fully coincides with that in the source language may depend on how well the speakers of the one know the other.

This also involves a comparison between preferences in borrowability of categories in direct diffusion and in indirect diffusion, and their relative chronology. Data from the Vaupés area suggest that indirect diffusion - which resulted in making an Arawak language, Tariana, structurally similar to East Tucanoan languages-preceded direct diffusion. Most changes achieved through indirect diffusion are completed, while the major parts of the direct diffusion are on-going and marginalized.

4. Can different language contact situations affect typologically different grammars in distinct ways? Will multilateral diffusion in a long-standing area without any dominance produce different results from one-to-one language contact without any dominance relationship; or from one-to-one contact with a dominance relationship, or from contact in a diglossic situation?

I suggest that multilateral diffusion in a linguistic area, without any relationships of dominance or diglossia, involves the enrichment of patterns. One-to-one language contact involves the levelling of structures, a kind of 'mutual adjustment' of the two languages. One-to-one language contact with dominance may result in rapid change (within one generation) leading to a considerable loss of patterns in what is becoming a minority language (the speed of such a forced language shift obviously depends on the degree of dominance in each particular case). One-to-one language contact with diglossia may lead to a considerable influx of loanwords. One such example comes from the Manambu language spoken in the East Sepik Province of Papua New Guinea, in a situation of stable diglossia with Tok Pisin and English. Unlike many other languages of the world, Manambu freely borrows verbs - besides nouns and adverbs, though not adjectives-from Tok Pisin (Aikhenvald 2008: 605-18).

5. And finally, how can language attitudes - such as a strong inhibition against the borrowing of forms and also the degree of the speakers' evaluation of their language as a meaningful token of their identity as a group, affect the preferences for borrowability? Is it possible that some of the assumptions of previously cstablished 'borrowability hierarchies' will be shown to be flawed? The answer is likely to be 'yes': Chapter 10 shows that in such language situation, the few accepted (and almost fully nativized) borrowed forms are bound, and not frec, morphemes. This is fully understandable - bound morphemes are not so easily recognizable as unwelcome 'intruders'. But this does go against one of the 'axioms' of borrowability - that free morphemes have to be borrowed before bound oncs.

Wc will now look at various patterns of Arawak Tucanoan language contact in Amazonia. 


\subsection{Arawak-Tucanoan Contact in Amazonia}

\subsubsection{Arawak and Tucanoan languages: general remarks}

Geographically, Arawak languages form the most extensive and the most diversified family in South America (see Aikhenvald 1999b, and Appendix 1 below), spanning Venezuela, Guyana, French Guiana, Surinam, Brazil, Colombia, Peru, Bolivia, formerly Argentina; and also extending into Central America. There is by now hardly any doubt as to the limits of the family. One can easily discern a smallish archaic 'nucleus' of Proto-Arawak grammar and lexicon (see Appendices 1 and 3). Individual languages spoken in separate (but often quite close) locations show a high degree of structural and formal divergence in other areas of the grammar, even if they share 50,60 , or even $70-80$ per cent lexicon. The differences between Arawak languages north of the Amazon make it very difficult to go beyond low-level subgroupings ( $\Lambda$ ikhenvald $2001 b$ ).

Little is known about the proto-home for the Arawak family. The linguistic argument in favour of an Arawak proto-home located between the Rio Negro and the Orinoco rivers, or on the Upper Amazon (advocated by Lathrap 1970 and Oliver $1989^{5}$ ), is the higher concentration of structurally divergent languages in this region, as compared to other Arawak-speaking areas. This area has also been suggested as one of the places where agriculture developed in the Amazon (Petcr Bellwood, personal communication). This is highly suggestive and corroborated by a few mythical traditions of northern origin by Arawak-speaking peoples south of the Amazon. The origin myths of the Tariana suggest that they could have come from the north coast (cf. the mention of the mythical creator woman "coming down from the ocean' in texts published in Aikhenvald 1999a).

The Tucanoan language family spans Brazil, Colombia, Ecuador, and northeastern Peru. West Tucanoan languages are spoken in south-western Colombia, Ecuador, and Peru. East Tucanoan languages are spoken in north-western Brazil and the adjacent arcas of Colombia, in the Vaupés river basin. Of the two Central Tucanoan languages, Cubeo is spoken in the Vaupés area and to the north-east of the Vaupés (rivers Querarí, Cuduyarí, and Pirabotón); and Retuarã/Tanimuca ${ }^{6}$ is spoken to the south-west of the Vaupćs (rivers Mirití, Oiyaká, and Apaporis). A 'state-of-the-art' classification of the Tucanoan languages is given in Appendix 1.

\footnotetext{
5 However, Oliver's scheme is based on Noble's (1965) and Matteson's (1972) classifications and his own lexico-statistic comparisons involving highly unreliable data from 30 languages. There are numerous mistakes in the words given for individual languages, as well as a confusion of language and dialect boundaries. This casts doubt on these hypotheses. Uibau (1992: 96) discusses tracing the origins of Arawak-speaking peoples to Peru, and to Lowland Amazonia. More detailed studies are needed.

${ }^{6}$ In the past the Retuarã spoke a different language from the Tanimuca; they are said to have adopted the Tanimuca language. The two groups maintain some dialectal differences (Camilo Robayo, personal communication; Strom 1992: 1-2).
} 
Most scholars concur that Tucanoan languages are likely to have originated to the west of the Vaupés region, in the hilly regions closer to the Andes than to the main area of concentration of East Tucanoan languages today (see Nimuendajú 1982; Ribeiro 1980; Urban 1992: 98). This is corroborated by stories told by the Vaupés Indians indicating their Andean connections (see Aikhenvald 1999a). An alternative hypothesis was put forward by Neves (1998: 249), that the area of the Vaupés and Pira-paraná basins (see the Map) 'corresponds to the place of origin and development of Proto-Tukanoan'. The argument is that this is 'the area of highest linguistic diversity within the whole Tukanoan family', 'with two out of three subgroupings being represented'. By the two subgroupings, Neves means East Tucanoan (see \$1.4) and Cubeo (Central Tucanoan). Linguistically speaking, this argument is flawed: East Tucanoan languages are very closely related (see cognate percentages in Aikhenvald 1999c; the ones in Neves 1998: 249 differ only slightly), and in fact can be considered a dialect continuum. They have also becn in constant contact for at least a few hundred years (see \$1.4). As a result, their status as a genetic or an areal subgroup has been obscured. Cubeo has been in constant contact with Baniwa-Kurripako, an Arawak language; and also with East Tucanoan languages. Its position within the family is problematic - Cubeo shares features with both East Tucanoan and West Tucanoan languages (cf. Waltz and Wheeler 1972; and the summary in Morse and Maxwell 1999: 2); and the number of cognates with East Tucanoan languages is quite high (around 70 per centcf. Neves 1998: 249). That is, the Tucanoan-speaking area of the Vaupés and Piraparaná basins is not all that linguistically diverse. On the contrary, the linguistic similarity between the 'languages' of each individual group is remarkable.

I conclude that prehistory, migrations, and especially the dates for the Tucanoan family remain a matter for discussion. But this does not affect my line of argument which is based on linguistic analysis and on oral histories.

\subsubsection{Known instances of Arawak-Tucanoan contact}

The five known foci of Arawak-Tucanoan language contact are indicated on the Map. (Map 2 in Aikhenvald $1999 b$ and Map 6 in Barnes 1999 show the distribution of $\Lambda$ rawak and Tucanoan languages.)

(I) MUltilateral DifFUSiON IN THE TRADitional LINGUISTIC AREA OF THE VAUPÉs. This area is known for its institutionalized multilingualism based on language group exogamy: one must marry a person belonging to a different language group. Language is acquired through patrilineal descent, and is a badge of identity for each person. Languages spoken in this arca include East Tucanoan and Tariana (Arawak). Tariana was formerly a dialect continuum (comparable in its diversity to East Tucanoan languages: see Aikhenvald 2003a). Traditionally, there were no relationships of dominance between language groups; intratribal hierarchies existed within each group and corresponded to dialectal subdivisions. A detailed 
discussion of the language situation and language etiquette in the traditional Vaupés area is given in $\S \S 1.4 .1$ to 1.4 .2 and forms the core of this study.

(II) UNILATERAL DIFFUSION FROM TUCANO (EAST TUCANOAN) TO TARIANA (ARAWAK). Newly introduced relationships of dominance between indigenous languages of the area-absent in the traditional situation of contact described in (I) above-have resulted in one-to-one language contact between modern Tariana (Arawak) and Tucano (East Tucanoan). Under the influence of white missionaries, the Tucano language has gradually acquired dominant status in the Brazilian Vaupés (see \$1.4.3).

(III) ONE-TO-ONE LANGUAGE CONTACT BETWEen YuCuna (NoRTH ARAWAK) AND RETUARÃ/TANIMUCA (CENTRAL TUCANOAN). The two groups live in the region of the rivers Apaporis and Miriti-paraná, south of the Vaupés area. In the past they were in close contact. There is no evidence of any dominance relationships. There is little bilingualism at present, and the existence of linguistic exogamy is problematic. ${ }^{7}$

(IV) ONE-TO-ONE LANGUAGE CONTACT BETWEEN BANIWA-KURRIPAKO ${ }^{8}$ (NORTH ARAWAK) AND CUBEO (CENTRAL TUCANOAN). The two groups live in the region of the Querarí river, north of the Vaupés area. There is very little, if any, linguistic exogamy (cf. Hill 1985), and little bilingualism (interestingly, the Cubeo sing Arawak traditional songs-see Gomez-Imbert 1996: 446; cf. also Morse and Maxwell 1999: 17). There is evidence, from oral histories, that at least some Cubeo-speaking clans previously spoke a dialect of Baniwa. The contact-induced changes in Cubeo are most probably due to language shift.

(V) ONE-TO-ONE LANGUAGE CONTACT BETWEEN CABIYARI (OR KAWIYARI) (NORTH ARAWAK) AND VARIOUS EAST TUCANOAN LANGUAGES. Cabiyari, an Arawak language spoken in the area of the Cananari river (an Apaporis tributary, to the south of the Vaupés river) is reported to be in contact with Barasano, an East Tucanoan language, and possibly with Carapana (Huber and Reed 1992; Metzger 1998). Almost no linguistic information is available on Cabiyari.

Speakers of the Arawak and Tucanoan languages share numerous cultural patterns. They are slash-and-burn agriculturalists with a very similar lifestyle, myths,

7 Clay Strom (personal communication) reports that there continues to be language exogamy between the Tanimuca and the Retuarã: the _Retuarã can marry the Tanimuca and vice versa, but neither can marry within their language group. Whether this is also the case with the Yucuna is not clear.

8 Baniwa-Kurripako form a dialect continuum; the individual dialects differ as to the degree of mutual intelligibility. A useful list of Baniwa-Kurripako dialects can be found in Nimuendajú (1982). and also Rodrigues (1986). Neither the Baniwa-which includes the groups in the basins of the Lower and Middle Içana rivers - nor the Kurripako-who live in the basin of the Upper Içana-are used as auto-denominations by the members of these groups. Baniwa is a variant of the Portuguese maniva, or maniwa 'manioc' (a loan from Língua Geral, a former lingua franca of Tupí-Guaraní origin). a staple food of the region; while Kurripako consists of kurri 'negation' plus pa-aku (impersonal prefix-speak), literally, "one says kurri for "no"'. The speakers refer to themselves with the names of particular dialects, such as Siuci, Hohôdene, and Dzawinai (for the Baniwa); or Kumandene and Ayanene (for the Kurripako). An alternative general term for both Baniwa and Kurripako is 'Içaneiro' (peoples of the Içana river); see \$1.4.1; also see Aikhenvald (1999b) and Taylor (1991: 7-8). 
and beliefs; and they have a similar degree of sophistication in their weapons and food-gathering techniques. All communities are tightly knit. The general tendency is to keep their languages apart by limiting the influx of borrowed forms. These similarities help reduce the number of potential sociolinguistic variables which might influence the outcome of language contact.

\subsection{Linguistic Situation in the Vaupés Area}

The multilingual area of the Vaupés basin-spanning Colombia and Brazil in central north-western Amazonia-has fascinated linguists and anthropologists for a number of years, since it was first described by Sorensen (1967), and then by Jackson $(1974,1976,1983)$ (also see Sorensen 1985; Grimes 1985). This area is known for its language group exogamy and institutionalized multilingualism. One must marry a person belonging to a different language group. Marrying someone who helongs to the same language group is considered incestuous and is referred to as being similar to 'what dogs do'. Language is acquired through patrilineal descent, and is a badge of identity for each person (Jackson 1983: 165).

The languages spoken in the Vaupés are discussed in $\$ 1.4 .1$. Then we look at the traditional Vaupés region as a linguistic area without dominance and its 'linguistic etiquette' (\$1.4.2). The present-day contact situation-characterized hy the dominance of the Tucano language-is discussed in $\$ 1.4 .3$.

\subsubsection{Languages spoken in the Vaupés}

Languages traditionally spoken in the Brazilian Vaupés belong to three unrelated genetic groups: East Tucanoan, Arawak, and Makú. (Previous studies have been concerned with the Colombian part of this linguistic area, where the multilingual marriage network is limited to East Tucanoan people.)

The East Tucanoan languages spoken in the area are Tucano, Piratapuya, Wanano, and Desano; there are also a few speakers of Tuyuca, Tatuyo, and Siriano; and there are some speakers of the Central Tucanoan language Cubeo. These languages are closely related, being just 'a little further apart' than Romance languages (Sorensen 1967). ${ }^{9}$

Tariana, the main Arawak language in the multilingual Brazilian Vaupés, was once a dialect continuum spoken by over 1500 people in various settlements along the Vaupés river and its tributaries. The Tariana clans used to form a strict hierarchy (according to their order of appearance as stated in the creation myth: see Brüzzi 1977: 102-3; Aikhenvald 1999a: 26, and Text 1 there). Lower-ranking

9 The Vaupés Indians are conscious of the close similarity between different Tucanoan 'languages'. They acknowledge close relationships between Wanano and Piratapuya (which are in fact close dialects with about $94 \%$ lexicon in common: see Aikhenvald 1999c), and say that Tucano is 'quite different' from these, while Cubeo is 'very different' and 'hard to learn'. Tariana-which belongs to a different family - is acclaimed as 'extremely difficult'. The Tariana consider each other blood relatives, while representatives of all other nations are called 'marriageable relatives', or 'in-laws'. 
groups in this hierarchy (referred to as 'younger siblings' by their higher-ranking tribespeople) would perform various ritual duties for their 'elder siblings'-for instance, they would light their cigar during the offering ritual (cf. the description by Brüzzi 1977). Each group spoke a different variety of the language. The difference between these varieties is comparable to that between individual East Tucanoan languages (data on dialects can be retrieved from Koch-Grünberg 1911, Wheeler n.d., and Giacone 1962; see a full analysis in Aikhenvald 2003a). Ranked sibs, or subtribes, are found throughout the Vaupés area-see the analysis in Hill (1985).

As the Catholic missions and-with them-white influence expanded, the groups highest up in the hierarchy abandoned the Tariana language in favour of the numerically dominant Tucano language. It is hard to know when exactly this process started; according to Koch-Grünberg (1911), some Tariana dialects in the area of lower Vaupés were close to extinction in the early 1900s. In the 1950s and 1960 s a number of high-class Tariana dialects were reportedly still known to older people (Giacone's 1962 grammar is based on a random selection of such varieties). Materials on a now extinct Tariana dialect were collected by Wheeler (n.d.): this dialect appears to be mutually unintelligible with the surviving dialects of Tariana.

As a result, in the Upper Vaupés area Tariana is actively spoken by only about 100 people. These belong to two subtribes of the lowest-ranking group Wamiarikune, and live in two villages: Santa Rosa and Periquitos. Minor linguistic differences exist between the varieties.

Sociolinguistically, they contrast in two ways. One is the degree of language maintenance - the Periquitos dialect is spoken by all generations, while the Santa Rosa is not: see Chapter 11. The other is the degree of acceptance of forms of East Tucanoan origin: a few loans considered to be unacceptable by the Santa Rosa people are treated as correct Tariana by those from Periquitos: see Chapter 10.

Santa Rosa is located about five hours (by a motorized boat) up the Vaupés river from the nearest mission, Iauaretê- where the bulk of high-ranking Tucanospeaking Tariana live and where some of the Santa Rosa Tariana have moved recently. Periquitos is situated still further up the Vaupés river-see the Map. (See Plates 1-4.)

Yet another dialect of Tariana-scarcely mutually intelligible with the Wamiarikune of Santa Rosa and Periquitos-is spoken by about 20 adults on the Iauari river (Middle Vaupés) (see details in Aikhenvald 2003a). This dialect is spoken in the context of multilingual exogamy with the Hohôdene dialect of Baniwa (Arawak) and Tucano; it is not discussed here.

Traditionally, there were no relationships of dominance between different East Tucanoan and Arawak-speaking groups in the Vaupés. Clear relationships of dominance existed (and to some extent still exist) between East Tucanoans and the Makú. 
The Maki are the putative autochthonuus inhabitants of the area (see \$1.4.2). Unlike the Arawak and East Tucanoan peoples, who are slash-and-burn agriculturalists and mostly live along big rivers, ${ }^{10}$ the Makú are nomadic hunters and gatherers and mostly live in the jungle, near small streams; they do not follow the rules of linguistic exogamy - which, in the eyes of the East Tucanoans and of the Tariana, makes them 'like dogs'. ${ }^{11}$ The Makú languages spoken in the Vaupés are Dâw, Hupda, and Yuhup (see Appendix 1, for classifications of the Tucanoan and Makú languages). They are drastically different from Nadëb, the Makú language spoken outside the area (Martins and Martins 1999).

The Maku are outside the marriage network and are considered ritually 'inferior' to the East Tucanoans and to the Tariana. They have traditional economic ties with the East Tucanoan and Arawak peoples (exchanging arrow poison and game for manioc, the staple food of their agricultural neighbours). The dominant groups had master-underling relationships with the Makú-hence denominations of the type 'Makú of Tucano', 'Makú of.Wanano', etc. The underlings would perform ritual duties - such as lighting the cigar during the ritual offering feast-for their masters. The Makú men would know an East Tucanoan language, women tending to be monolingual. The Tariana have no Makú-underlings of their own. ${ }^{12}$

Other North Arawak languages currently spoken along the tributaries of the Upper Rio Negro (on the outskirts of the Vaupés area) are:

(i) Baniwa of Içana/Kurripako dialect continuum, with its large dialect groups Siuci and Hohôdene, closely related to Tariana, and spoken by $3000-4000$ people on the middle Vaupés, the Içana and its tributaries, and in the adjacent regions of Colombia and Venezuela (see the lists of dialects in Nimuendajú 1950/5, Rodrigues 1986).

(ii) Warekena, a dialect of Baniwa of Guainia (mainly spoken in Venezuela); spoken hy a few dozen old people on the Xié river (see Aikhenvald 1998b);

(iii) Old Warekena (also called Warena, or Guarequena); spoken by a few old people on the Xié river, and by a few hundred people in Venezuela where they moved early last century (Aikhenvald 1998b);

(iv) Bare; once the most important language along the Upper Rio Negro, but now probably extinct (see Aikhenvald 1995a);

(v) Piapoco, spoken hy about 3000 people to the north-east of the Vaupés in the basin of the Meta, Vichada, and Guaviare rivers in Colombia (Klumpp 1990, 1995).

10 With the exception of the traditional Desano who used to live ncar small streams.

11 The Makú groups of Dâw (Elias Coelho, personal communication) and Hupda (Renato Atias, personal communication) must have traditionally had exogamy between their clans. The rules of marriage between Tucanoan people and Tariana speakers involve a number of complexities, probably historically motivated (see Jackson 1983, and also Neves 1998); see also Figure 1.1.

12 The Santa Rosa Tariana tell me that they used to have Makú 'underlings' of their own, who they called Mayhene, lit. 'beetles'. They are said to have fled to Manaus. It is not known what language they used to speak. This story may relate to the intensive slave trade by the Tariana with the now extinct Manao (who gave their name to the city of Manaus) as middlemen - see Neves (1998: 370-1). 
The North Arawak languages of the Içana and Vaupés and the adjacent regions of the Upper Rio Negro basin fall into three distinct genetic groups: (a) Warekena; (b) Bare; and (c) Baniwa, Tariana, Old Warekena, and Piapoco. Within this last group, the Baniwa dialect of Hohôdene (and possibly other dialects) are in contact with Tariana. At present, there is no contact between Tariana and Piapoco.

According to the oral histories of the Tariana of Santa Rosa, in the past there was substantial contact between them and Old Warekena (this information is confirmed by Father Casimiro Bekšta, personal communication, for other Tariana groups). At present, there is no contact between them.

A comparison between Tariana and the Arawak languages spoken outside the Vaupés area is crucial for distinguishing between areally diffused and genetically inherited patterns in Tariana. However, the existing structural and lexical similarities between Tariana and Baniwa could be due to their common origin, in combination with language contact: these languages are spoken in a macroarea of diffusion, which covers the Içana and Vaupés river basins (Aikhenvald $1999 c$, and discussion in Aikhenvald 2001b). Tariana maintains some contact with the Baniwa dialect of Hohôdene-whose percentage of shared lexicon with Tariana is the highest of all the Baniwa varieties (see Tahle 1 in Appendix 3; and $\S 8.3$ ). To prove the genetic - and not areal-origin of a feature, a comparison of Tariana with varied dialects of the Baniwa-Kurripako complex and with Piapoco is essential (see §1.5).

Linguae franche spoken in the region are Língua Geral, or Nheengatu, and Tucano. Língua Geral is spoken in the whole region of the Upper Rio Negro (see Rodrigues 1986; Bessa Freire 1983: Moore et al. 1994). On the Vaupés, it is only understood by older people. Língua Geral is a creolized version of Tupinambá (Tupi-Guarani family) which was spread from the east coast of Brazil by white merchants and missionaries. It was the lingua franca of the entire A mazon region from the late 17th century up to the middle of the 19th century, and the influence of it can still be seen in a few loanwords in Tariana and other languages of the Vaupés. It was gradually replaced by Tucano as a lingua franca, as a result of the language policy of Catholic missionaries and of the civil authorities. Loans from Língua Geral into Tariana are discussed in Chapter 10.

Indo-European languages are represented hy Portuguese (on the Brazilian side) and Spanish (on the Colombian side). In particular, Portuguese is gaining ground as a lingua franca of the region, especially among younger people.

Most schooling is in Portuguese (a little Tucano is tanght at a secondary college in the mission centre). Switching to Portuguese, the 'white man's language', is obligatory in all the environments associated with 'white people': schools, church services, sports and games, hospital, and commercial activities. See Silva (1999), on the expansion of Western-style football in the Vaupés environment and the competitive spirit that goes with it (and see Schmidt 1987: 203, on the high frequency of Standard Fijian forms in a special speech style used during netball games in a Fijian village, since this sport was acquired through the school system). All written 
communication between literate Indians is in Portuguese. ${ }^{13}$ There is a diglossic relationship - that is, a 'complementary distribution'-between the domains where Portuguese is used and those where the indigenous languages of the Vaupés are used: see the discussion in Chapters 7 and $8 .{ }^{14}$

The Yanomami-semi-nomadic hunters and gatherers who live in the jungle around the minor tributaries of the Upper Rio Negro and sometimes travel as far westwards as the Vaupés region-are not culturally integrated with other peoples of the Upper Rio Negro, and do not form a part of the Vaupés linguistic area. They rarely interact with other tribes, being feared and avoided.

The relationships between languages in the traditional Vaupés and problems with reconstructing their ethnohistoric background are discussed in \$1.4.2.

\subsubsection{The traditional Vaupés area}

Multilingualism used to be-and to a great extent still is-the cultural norm over the whole Vaupés region. Among East Tucanoan peoples and Tariana, marriage is exogamous. Strict marriage rules are governed by language affiliation (see Sorensen 1972; Aikhenvald 1996a). Jackson (1974: 62) reports being told: 'My brothers are those who share a language with me', and 'We don't marry our sisters', referring to the linguistic attitudes of the Bará. Marrying someone who belongs to the same language group is considered akin to incest and referred to as being 'what dogs do' (an expression trequently used in all the indigenous languages of the Vaupés). The Indians' 'main' language is the language of their patrilineage, and is a badge of identity for each person (Jackson 1983: 165). As a result, in spite of the traditional multilingualism enhanced by language-based exogamy, Indians identify themselves with just one language - that of their father. In this language the Indians would consider themselves - and be considered - as both the owner and an authority (no matter how fluent they may be in other languages of the region).

Hypothetically, all possible combinations of languages could be encountered in a multilingual village or a long-house. This is not the case, due to the operation of marriage principles and strong hierarchical relations between subtribes.

13 The vast majority of the population of the Brazilian Vaupés are practising Catholics. Most people aged between 20 and 60 are at least functionally literate in Portuguese, thanks to the obligatory schooling imposed by the Salesians. Recently, literacy in Tucano has been introduced. It is acknowledged by the vast majority as 'too complicated' and is hardly ever used (except in some church materials distributed by the mission centre and in the notices and prayers on the mission walls produced by Salesians).

14 Hardly any non-Indians speak indigenous languages. When there is a white person around, the interaction is in Portuguese-for those who feel confident about it. Those who do not remain silent. Some still use Tucano as an 'unmarked' lingua franca of the area. Once I visited a Piratapuya-speaking household (accompanied by the Santa Rosa Tariana family I stayed with). A younger person addressed me in Portuguese, but the old lady of the house muttered a greeting in Tucano. Indians who consider themselves 'in charge' of the situation make a point of using their own language. During my stay in the Tariana village of Santa Rosa one of the few shamans on the Vaupés, a Wanano himself, paid us a brief visit. He spoke to me in Wanano, to show his status; and then switched tn Tucann, to make himself understood by 'women who only speak Tucano' (he was said to know no Portuguese). 
Tariana

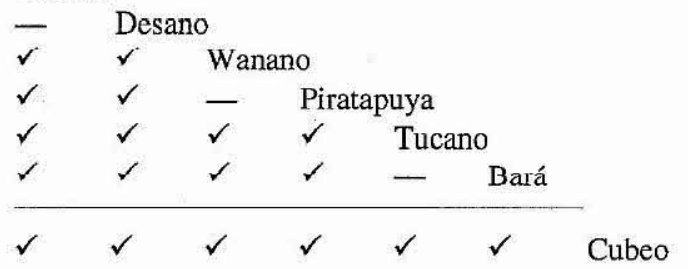

Figure 1.1. Marriage possibilities between language groups in the Vaupés area

For example, Wanano and Piratapuya are considered 'brothers', and so they do not intermarry (I do not know to what extent this is due to the closeness of these languages). The same applies to Bará and Tucano (see Jackson 1974: 56). According to my teachers of 'Tariana, Desanos are 'younger brothers' of Tarianas; consequently, they do not intermarry (also see Brüzzi 1977). This reflects a hierarchy of tribes: a 'younger brother' is an equivalent of a 'underling' (see C. Hugh-Jones 1979). It may have a historical explanation: according to Koch-Grünberg (1906b), the Desano are descendants of a 'Tucanized' Maku tribe.

Figure 1.1 shows marriage possibilities between language groups in the Vaupés area (here I do not mention groups with very few representatives in Brazil, such as Tuyuca, Carapana, Tatuyo, Macuna, Sirianó, and Barasano; except for the Bará; also see Neves 1998: 249).

For each group there is one other group that they cannot marry into. The prohibitions are:

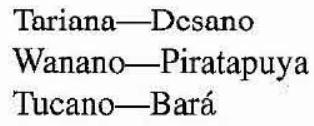

The Cubeo come from outside the region and there are no prohibitions concerning who they can marry. ${ }^{15}$

So, theoretically one should not find long-houses or settlements with Bará and Tucano, Wanano and Piratapuya, or Tariana and Desano as mother-languages because of the prohibition against the intermarriage between representatives of these groups. This does not exclude the actual knowledge of these languages by the people, though they may not admit it to an outsider. Sorensen (1967) and Grimes (1985) report how strict the Vaupés Indians are in evaluating the degree of knowledge of a language: only those who have a native-speaker-like proficienicy in a language would acknowledge they actually 'know' it. This also explains the

\footnotetext{
15 However, according to Wanano oral histories, the Cubeo appear to have been in the Vaupés areas long before the other tribes (Nathan Waltz, personal communication). Curiously, the term 'Cubeo' is used as a cover denomination for all the Indians in the area, both those speaking East Tucanoan languages and those speaking Tariana.
} 
virtual lack of semi-speakers: people who are not fully proficient are scared to open their mouth (unless they are drunk): see the discussion in Chapters 9 to 11 .

Since language identity is the badgc of ethnic identity, languages even the closest ones-are kept strictly apart (see Sorensen 1972: 82). This creates a very strong impediment to lexical loans, in contrast to other multilingual situations, e.g. the village of Kupwar (Gumperz and Wilson 1971: 161-2), or multilingual Jewish communities. Linguistic awareness of what is correct-viewed in terms of sensitivity to foreign forms and structures-is discussed in Chapter 9.

According to the languagc 'ctiquctte' of the area, one is supposed to speak the language one identifies with - that is, one's father's language-to one's siblings, father, and all his relatives, and one's mother's language to one's mother and her relatives. It is also polite to speak the language of onc's gucst, or of the majority of the people around, in order 'not to exclude them'. When a Piratapuya family came to the Tariana-speaking household of Cândido Brito, one of the oldest speakers and most loyal keeper of tradition, he conversed with them in Piratapuya (his wife Maria, a Piratapuya herself, joined them later). When another Piratapuya (also married to a Tariana) dropped by, she immediately joined in, in the same language. However, when Glória-a Piratapuya woman who is known to 'have lost her language' and speaks just Tucano and regional Portuguese-came in, the whole group switched to Tucano.

Making a point of speaking one's own language - no matter what-is a way of showing 'who is in charge'. Marino, one of the most traditional speakers of Periquitos Tariana, was vociferously criticized-behind his back-for speaking Tariana to his Santa Rosa relatives in front of those Tariana who had 'lost thcir language': this behaviour was perceived as a linguistically aggressive way of asserting himself and his superiority. Numerous representatives of the Santa Rosa Tariana expressed their resentment to me and to each other-and especially to their elder, Cândido. Marino was said to 'want to be better than others' (without sufficient reason). Since Tucano is the majority language, most Tucano speakers-especially males-insist on always speaking Tucano with no regard to the linguistic affiliation or the competence of their interlocutors. When a speaker of Tucano comes in, everyone switches to Tucano (similar reports can be found in C. Hugh-Jones 1979, and Jacksun 1983; see alsu \$1.4.3).

The choice of language in everyday communication is thus determined by two factors: first, by traditional language etiquette and politeness, and secondly, by an association between language and status. However, Tucano, rather than Portuguese, is nowadays often used as a language of power (unlike Spanish in the Nahuatl context-see Hill and Hill 1980), while Portuguese is obligatory only in some contexts. We return to this in \$1.4.3.

The linguistic area of the Vaupés is characterized by numerous features shared by genetically unrelated languages. Most cultural features are also shared. These include the means of gardening, food, tabous and prescriptions, sturies and rites, as well as the traditional social structure and a Dravidian-type kinship system, 


\section{1. Language Contact and Language Change in Amazonia}

based on a difference between 'unmarriageable' parallel cousins and 'marriageable' cross-cousins (who belong to a different tribe). The division of 'labour' between tribes is minimal (see Brüzzi 1977; and Galvão 1979 for the differences in pottery and basket-weaving techniques between 'Iucanoan and Arawak-speaking groups). Each group - and each subtribe--do have their own versions of origin myths.

We will see throughout this book that there is a large degree of grammatical and phonological indirect diffusion and convergence among the indigenous languages of the Vaupés. This diffusion was multilateral in the past, because of the interaction of at least half a dozen East lucanoan languages with a similar number of Tariana varieties. The impact of these convergence phenomena is especially instructive in the case of Tariana, since they are discernible as the result of 'foreign' influence.

The age of the Vaupés area-in terms of absolute figures-is unknown. However, oral histories, anthropological materials, and recently undertaken archaeological research (e.g. Neves 1998) suggest that the multilingual and multilateral diffusion area based on exogamous intermarriage with no relationship of dominance must be at least several hundred years old. The pre-European contact origin of the area was advocated by Aikhenvald (1996a); and corroborated by findings in Neves (1998). There is no reason to believe (pace Jackson 1983) that the multilingual Vaupés formed only recently as the result of decimated Indian tribes coming together and working out rules for survival.

Historical and traditional evidence shows that neither Tucano nor Tariana are the autochthonous population of the Vaupés. According to Nimuendajú (1982), the original inhabitants of the Vaupés area were Makú tribes, and East Tucanoan tribes are believed to have invaded the area from the West (but see the discussion in $\$ 1.3){ }^{16}$

However, the idea that the Makú are the autochthonous population of the area is founded on an assumption-made by archaeologists and anthropologists-rather than on tangible facts. The assumption is that nomadic hunters and gathererssmaller in size and darker in skin colour than their neighbours-are bound to be autochthonous to the area, and that the more sophisticated agriculturalists are bound to be newcomers (cf. Béteille 1998, on frequent misconceptions associated with the notion of indigenous people). Once again, more studies are required.

One point seems to be clear, and accepted by everyone: that the Tariana are the most recent arrivals in the Vaupés. They came into the area from one of the tributaries of the Içana river, probably the Aiari (see Brüzzi 1977; Koch-Grünberg 1911; Nimuendajú 1982, and Neves 1998). The origin of the Tariana is documented in the myths and the oral history of the speakers: according to them, the Tariana

\footnotetext{
16 Wanano oral histories go against this statement, indicating that at least some groups could have come from the east or south-east (Nathan Waltz, personal communication). This controversy can only be solved by a careful examination of the oral histories of all the indigenous groups of the area and the subclans within them, combined with archaeological examination; this goes beyond the scope of the present study.
} 
originated from a 'hole' at the waterfall of Wapui, on the Aiari river. It is not entirely clear which way the different subtribes of Tariana chose to get from Wapui to the Vaupés area. Quite possibly, different suhgrouns took different routes at varied times (the distance is not all that far, less than 50 kilometres through difficult terrain-see the account by Neves 1998: 176, 200). There are numerous accounts about the Tariana fighting their way with varions Fast Tucanoan groups before settling around Iauaretê and adjacent communities. According to results obtained by Neves (1998), the arrival of the Tariana in the Vaupés area goes back to precontact times. This agrees with the hypotheses put forward hy Brïzizi (1977), and Nimuendajú (1982). ${ }^{17}$

But a word of caution is in order. The important thing about the numerous subgroups of the Tariana-who used to speak different, often mutually unintelligible dialects--is that they also had different ethnic oral histories, different ideas about the relative position of each group on an intratribal hierarchy, different names for these groups, and different versions of origin myths and other myths. ${ }^{18} \mathrm{I}$ will mention just one example. Frequently quoted accounts of wars with the Wanano (East Tucanoan) were collected from mostly Tucano-speaking Tariana in the first half of the 20th century and at the end of 19th century - see Rrandão de Amorim (1987); Biocca (1965); Brüzzi (1994: 261-3), and also Stradelli (1890). They were used as a basis for Chernela's (1993: 24) statement that the Tariana fought and displaced the East Tucanoan group in the Vaupés at the time of their migration. These stories are perfectly valid and presumably true, but they reflect the history of just one Tariana group-called Itfirimhene by the Tariana of Santa Rosa. This group, known to be the most belligerent of the Tariana, now occupy the settlement of Dom Bosco (part of the mission centre of Iauaretê). The Itfirimhene shifted to speaking Tucano at least a generation ago.

Moreira and Moreira (1994: 55-61) report fights between two grouns of the Tariana. This is a history of the Kaline group, who now speak Tucano and live in various settlements on the Upper Vaupés. ${ }^{19}$

The Wamiarikune of Santa Rosa and Periquitos-the only surviving group in the Upper Vaupés who still speak the language-have markedly different origin myths and ethnic history. They deny ever having fought any wars with the Wanano. They are aware of a war with the Desano fought by the Tariana: the Desano were reportedly defeated, and adopted as 'younger brothers' of the Tariana.

17 Much later dates were proposed by Hugh-Jones (1981: 42) and Chernela (1993: 24), with no principled justification. These dates (c. 18th century) just wouldn't allow enough time for the diffusion that did take place between Tariana and East Tucanoan languages discussed throughout this book.

18 This is also the case with hierarchically organized subgroups of East Tucanoan people. I am indebted to Dominique Buchillet for pointing out to me the existence of different versions of intratribal hierarchies and myths among the Desano, and to Janet Barnes for pointing out dialectal differences among hierarchically different groups of Tuyuca. As far as I know, these differences have never been discussed in the relevant linguistic or anthropological literature.

19 According to the Wamiarikune of Santa Rosa, the Kaline are not 'true' Tariana: they are a group of Makú people who shifted language to Tariana (text 1 in Aikhenvald 1999a), and then to Tucano. 


\section{1. Language Contact and Language Change in Amazonia}

As a consequence, the Tariana cannot intermarry with the Desano, since blood relatives do not intermarry (cf. Chapter $2 \mathrm{fn} .1$ ). ${ }^{20}$ And in the origin myths told by the Kaline (Morreira and Morreira 1994: 28), the Tariana had three ancestors. In the origin myths told by the Wamiarikune of Santa Rosa there were consistently just two. And so on.

The moral of this is simple-these different accounts create insurmountable obstacles to an informed description and reconstruction of Tariana ethnic history. Recently, a goodly amount of archaeological research has been undertaken in the Vaupés (Neves 1998). The results provide a scientific foundation for some migrations and settlements of the Tariana, in particular around the settlements of Dom Bosco (the Itfirimhene group) and Marabitana (the Kaline group). Neither of these groups now speak Tariana. And next to nothing is known about the prehistory of the Wamiarikune group, for whom no archaeological or other sites have been explored. To what extent can we extend our knowledge about one group to another group whose history and migration routes could have been quite distinct? Too many pieces are missing from the jigsaw puzzle of Tariana history. Extreme caution is required in evaluating any data or ideas, in drawing conclusions, and in suggesting dates.

All we can conclude is that the traditional Vaupés region was a long-standing linguistic area with multilateral diffusion, and with no dominance relationships between the main participants-East Tucanoans and Arawak. The arrival of the Tariana groups created the first major punctuation. Considerable time, however, elapsed between this punctuation and the present moment, and this has enabled the area to form. During this time-probably a few hundred years-diffusional phenomena discussed in Chapters 2 to 6 occurred; these now reflect COMPLETED CHANGES.

The first contacts with Portuguese and Língua Geral took place in the second half of the 18th century (see the discussion by Neves (1998) of the impact of white invasion and particularly of the slave trade in the Vaupés on the structure of indigenous settlements). And, towards the end of the first half of the 20th century, a new kind of contact situation emerged.

\subsubsection{A new contact situation: Tucano in the Vaupés area}

Catholic missions were fully established in the Brazilian Vaupés in the 1920s. Missionaries insisted that just one language be spoken, choosing Tucano for this purpose (see $\$ 11.1$ ). The Tucano language started gradually acquiring a dominant status in the Brazilian Vaupés, creating a new situation of unilateral dominance. The effects of this rising unilateral dominance on Tariana, an Arawak language, are especially instructive. Linguistic diffusion from Tucano to Tariana was

\footnotetext{
20 However, Cândido Brito, the most knowledgeable expert on Tariana history, was not sure whether this war was fought by his ancestors or by some other group.
} 
TABLE 1.1. The Brazilian Vaupés: languages and their speakers

\begin{tabular}{lllllll}
\hline & Tucann & Piratapuya & Wanano & Desano & Cubeo & Tariana \\
\hline People & 4500 & 1232 & 1000 & 1800 & 3000 & 1500 \\
Language speakers & 4500 & 200 & 200 & 150 & 300 & 100 \\
\hline
\end{tabular}

speeded up; and Tariana gradually hecame obsolescent. (The impact of a growing dominance of the Tucano language on other, closely related, East Tucanoan languages is a matter for separate study.)

This process probably started in the mid-1920s when the Salesian missionaries established themselves in the area; it became stronger as the years went by. Most speakers who were born from the late 1940s onwards display the effects of this contact situation (see Appendix 5).

Table 1.1, based on Grimes (1988), gives an idea of the approximate numbers of those who identify themselves as belonging to East Tucanoan groups and to Tariana, Piratapuya, Wanano, Desano, and Cuhen, and those who actually speak the language. That is, in the Brazilian Vaupés, every language group, with the exception of the Tucano themselves, appears to be endangered. However, only Tariana is in real danger of extinction, since all East Tucanoan languages are still spoken by substantial numbers of people on the Colombian side, and Tariana has never been spoken in Colombia.

The main consequence of the recent spread of the Tucano language in the Brazilian Vaupés is a gradual undermining of the one-to-one identification between language and indigenous group. The Tucano and Tucano-speaking 'upper class' Tariana are numerically the largest and politically the most important group. This is a threat to what we conceive of as erstwhile 'egalitarian' multilingualism and language diversity (in the sense of Haudricourt 1961, and Hill and Hill 1980: 321).

The discrepancy between the number of people who helong to a tribe and those who actually speak the language is particularly marked in the case of Tariana. Those who 'lost' their father's language are referred to as 'those who speak a borrowed language' and therefore have nothing to identify with (Tariana $n a-$ sawayã na-sape lit. 'they borrow they speak'). They are treated with a mixture of pity, contempt-and envy (since quite a few of them have managed to achieve a coveted economic status). For those who still speak Tariana this language has particular value as a mark of 'linguistic solidarity', a characteristic of linguistic minorities all over the world (cf. Woolard 1989, among others).

The reduction of multilingualism engenders significant changes in linguistic behaviour. We can recall, from $\$ 1.4 .2$, that-according to the language 'etiquette' of the area-one is supposed to speak the language one identifies with (that is, one's father's language) to one's siblings, father, and all his relatives; and one's mother's language to one's mother and her relatives. Most Tariana speakers of 
Santa Rosa follow this pattern: they speak Tariana to their father and his classificatory brothers, and East Tucanoan languages (Piratapuya, Tucano, or Wanano) to their mother and her generation. However, the 20- to 40-year-olds tend to speak Tucano among themselves and to their children, saying that 'this is easier' and that 'otherwise women won't understand'. As a consequence, their children can at most understand Tariana, but none of them can speak it.

In contrast, most Periquitos Tariana speak Tariana to the representatives of their father's generation and among themselves. When addressing their children they use Tariana, Tucano, or Wanano; when they speak to their wives, they prefer their wives' languages (Tucano or Wanano). As a result, all the children have some competence in Tariana; only some are fluent.

The spread of Tucano is especially strong in Iauaretê, a large mission settlement where most of the 'higher-ranking' Tariana groups are concentrated, and in villages comparatively close by. The spread of Tucano in Periquitos-which is much further up the Vaupés river-is less strong. However, as some of the Periquitos Tariana move to Iauaretê for the purposes of schooling and in search of a 'better' life, the Tariana language is likely to become endangered even there. The obsolescence of Tariana, and prospects for the future of this language, are outlined in Chapter 11.

\subsection{Materials Used for this Study}

I intend to analyse and compare the following language contact situations:

(a) the long-term multilateral diffusion in the Vaupés as a linguistic area;

(b) the present-day one-to-one language contact situation between Tariana and the dominant Tucano; and

(c) the developing diglossic relationship between Tariana and Portuguese, the national language of Brazil.

The results of (a) and (b) will be compared-insofar as this is possible-w vother instances of Arawak-Tucanoan language contact (see \$1.3.2).

The basis for this work is a large corpus of fieldwork material on the Tariana of Santa Rosa and of Periquitos. The materials consist of over 1700 pages of texts of different genres, in addition to word lists, conversations, and other field notes. I have worked or been in contact with over 90 per cent of the speakers of the Santa Rosa dialect, of all the generations, and with over 70 per cent of those from Periquitos. Further information on the grammar of Tariana can be found in other of my publications (Aikhenvald 1994a, 1994b, 1998a, 1999d-19999e, $2000 c, 2000 d, 2001,2003 a, b)$. The cultural background of the Tariana, and areal diffusion, were discussed in Aikhenvald $(1996 b, 1999 a, 1999 b, 1999 c)$.

In this analysis I distinguish the more archaic language of the older generation from the speech of more innovative speakers (see Appendix 5). I alsu rely on speakers' judgements on what is correct and good Tariana-this basically corresponds to older patterns found in the language. Note that Ramirez (2001)'s conclusions 
concerning Tariana are not taken into account here since he used speakers whose main language was Baniwa and who mixed Baniwa into the Tariana they provided (see Aikhenvald 2001e).

Comparison of Tariana with related Arawak languages is essential for distinguishing areally diffused patterns from inherited ones. For this purpose I employ my own field data and additional existing sources on other North Arawak languages of the region. These are:

- Baniwa-Kurripaco: about 300 pp. of texts in Hohôdene and Siuci dialects; an unpublished dictionary with about 1000 entries; data and analysis from Aikhenvald 1995b, 1996c (the same set of data is discussed by Baltar 1995); manuscripts by França (1991), Garcia Salazar (1991), and Hurko (1991); additional data in Taylor (1991); and also Valadares (1994) on the Kumandene dialect.

- Warekena of Xié: a grammar by Aikhenvald (1998b) based on 200pp. of texts, and also fieldnotes and wordlists.

- Old Warekena, Warena, or Guarequena: very little is known, the only sources being a brief wordlist collected by Cristiane Cunha de Oliveira (1994); papers by Gonzalez-Ñanez (1970, 1990, 1991); and a wordlist by Nimuendajú (1932).

- Bare: a grammar by Aikhenvald (1995a, and references therein) based on over $150 \mathrm{pp}$. of texts, fieldnotes, and wordlists (working with the last known speaker).

- Piapoco: a detailed grammar by Klumpp (1990) and dictionary by Klumpp (1995).

- Yucuna: a grammar by Schauer and Schauer (1978). ${ }^{21}$

I also rely on Proto-Arawak reconstruction and internal reconstruction-Payne (1991), Aikhenvald (1999b), Seki and Aikhenvald (forthcoming), and Aikhenvald $(2001 b)$. References to data on other Arawak languages listed in Appendix 1 are in Aikhenvald (1999b).

For East Tucanoan languages, I rely on:

- Tucano: a grammar and a dictionary by Ramirez (1997); in addition to Brüzzi (1961, 1967), West $(1979,1980)$, West and Welch (1967), Goehner et al. (1985), and my own field notes.

- Desano: Miller $(1976,1999)$.

- Wanano (also spelt Guanano): Waltz $(1976,1977,1979,1981)$, Waltz and Waltz $(1967,1997)$.

- Other East Tucanoan languages: Piratapuya: Klumpp and Klumpp (1976) and my own notes; Carapana: Metzger (1981) and papers by Gomez Imbert (1982, 1993); Barasano: Jones and Jones (1991) on Barasano and papers by Gomez-Imbert $(1982,1985,1986 a, b, 1988,1993,1995,1997 a, b, 1998$, forthcoming) on Barasano and Tatuyo; Tuyuca: papers by Barnes; Cubeo:

21 I am grateful to Camilo Robayo for providing additional information on Yucuna. 
Morse and Maxwell (1999), Morse, Salser, and Salser (1999), Gomez-Imbert (1996); Retuarã: Strom (1992).

Grammars of West Tucanoan languages include Wheeler (1987), for Siona; Johnson and Levinsohn (1990), for Secoya; Velie Gable (1975), for Orejon; and Cook and Criswell (1993) for Coreguaje.

Barnes (1999) provides a general vision of Tucanoan languages. Additional information on comparative East Tucanoan, West Tucanoan and Proto-Tucanoan and Proto-West Tucanoan comes from Barnes (1999), Barnes (1980), papers in Levinsohn (1992), Gomez-Imbert (1993), Malone (1988), Metzger (1998), and Waltz and Wheeler (1972).

\subsection{The Structure of this Book}

This book is intended to serve several purposes. First, it attempts a systematic study of the ways in which language contact may affect the linguistic structure of genetically unrelated languages, in a multilingual situation. My second goal is to formulate hypotheses concerning which categories are more likely and which are less likely to be affected; and which units of speech most readily undergo language change under contact. To achieve this, it is important to look at what are the sociolinguistic parameters at work in the different contact situations which I consider here. For this reason, the chapters dealing with the sociolinguistic aspects of the language contact patterns follow the discussion of which areas of the grammar become affected by the diffisional phenomena.

This book effectively spans historical linguistics, language typology, and sociolinguistics. Historical and comparative issues within the Arawak and Tucanoan familics-discussion of which is impossible without the provision of information on the typology and grammar of these languages-are considered in Chapters 2 to 6. In each case, the major focus of discussion is the Vaupés area. Additional information on other foci of Arawak-Tucanoan contact is provided if available. Appendices 1 to 3 contain additional synchronic, historical, and comparative data on Arawak languages, and can be consulted while reading Chapters 2 to 6 .

In Chapter 2 I discuss the arcal impact of East Tucanoan languages on Tariana phonology. Morphological profile and pronominal systems are the points on which the East Tucanoan and Arawak languages differ most, and this is what makes them look typologically incompatible in significant ways. Chapter 3 discusses how areal diffusion-from Tucanoan into Arawak and from Arawak into Tucanoan -helps 'bridge' these differences and contributes to the complexities in grammatical structure of the languages in contact. Areal diffusion and its impact on nominal categories is discussed in Chapter 4; while Chapter 5 considers the restructuring of verbal categories. Diffusional phenomena in syntax and in discourse are dealt with in Chapter 6.

Chapter 7 discusses the impact of a different contact situation, that between Tariana (Arawak) and Portuguese - the national language of Brazil-in 
the Vaupés area. This recently arisen situation is characterized by diglossia and by a certain relationship of dominance. This chapter focuses on both on-going language change and on concomitant sociolinguistic parameters. (No data are available on the impact of Spanish or Portuguese on other Arawak or Tucanoan languages of the area.) Appendix 4 contains a description of Tariana and East Tucanoan interference in Portuguese which results in the creation of a somewhat different variety of this language.

The next two chapters provide a sociolinguistic perspective on the Vaupés. In Chapter $8 \mathrm{I}$ discuss code-switching and code-mixing rules and inhibitions for the different languages of the area-which include East Tucanoan languages, Portuguese, Baniwa, and Tariana dialects. The mechanisms of 'language awareness' which help monitor language change, and determine what is correct Tariana and what is not, is the topic of Chapter 9.

After the facts have been analysed and the general sociolinguistic background discussed in detail, we go on to a summary of the outcomes of direct and of indirect diffusion-this is the topic of Chapter 10. There I also discuss instances of incomplete convergence within the Vaupés area, and problems of identifying independent innovations in Tariana.

An additional parameter of language change in the present-day Vaupés area is language obsolescence. In Chapter $11 \mathrm{I}$ look at how language obsolescence affects previously established patterns of areal diffusion; and the new developments in the language it brings about. This chapter covers the issues of language change and of sociolinguistic conditioning for language attrition. I also discuss problcms concerning language maintenance in a multilingual and in a multidialectal environment. Appendix 5 describes the language proficiency of the current speakers of Tariana and their children. This is relevant for Chapters 8, 9, and 11.

Chapter 12 draws together the results of different kinds of language contact and their outcomes discussed in the previous chapters, putting them in a crosslinguistic perspective and outlining prospects for future studies. 